\title{
Soil Degradation and Restoration in Southwestern Saudi Arabia through Investigation of Soil Physiochemical Characteristics and Nutrient Status as Indicators
}

\author{
Ahmad A. Al-Ghamdi ${ }^{1}$, Yilma Tadesse ${ }^{1}$, Nuru Adgaba ${ }^{2}$ and Abdulaziz G. Alghamdi ${ }^{3, *}$ (]) \\ 1 College of Food and Agricultural Sciences, King Saud University, P.O. Box 2460, Riyadh 11451, Saudi Arabia; \\ aalkhazim@gmail.com (A.A.A.-G.); yiltadesse@gmail.com (Y.T.) \\ 2 Department of Plant Protection, College of Food and Agricultural Science, King Saud University, \\ P.O. Box 2460, Riyadh 11451, Saudi Arabia; nuruadgaba@gmail.com \\ 3 Department of Soil Sciences, College of Food and Agricultural Sciences, King Saud University, \\ P.O. Box 2460, Riyadh 11451, Saudi Arabia \\ * Correspondence: agghamdi@ksu.edu.sa; Tel.: +966-11478445
}

check for updates

Citation: Al-Ghamdi, A.A.; Tadesse, Y.; Adgaba, N.; Alghamdi, A.G. Soil Degradation and Restoration in Southwestern Saudi Arabia through Investigation of Soil Physiochemical Characteristics and Nutrient Status as Indicators. Sustainability 2021, 13, 9169. https://doi.org/10.3390/ su13169169

Academic Editor: Jose Navarro Pedreño

Received: 12 July 2021

Accepted: 9 August 2021

Published: 16 August 2021

Publisher's Note: MDPI stays neutral with regard to jurisdictional claims in published maps and institutional affiliations.

Copyright: (c) 2021 by the authors. Licensee MDPI, Basel, Switzerland. This article is an open access article distributed under the terms and conditions of the Creative Commons Attribution (CC BY) license (https:/ / creativecommons.org/licenses/by/ $4.0 /)$.

\begin{abstract}
Soil degradation is among the major global concerns resulting in declined soil fertility, loss of soil organic carbon (SOM) and nutrients, and reduced pollinator visitations. The current study was performed to explore soil quality and fertility after restoration in southwestern Saudi Arabia, as new plantation could alter soil properties. A total of 78 soil samples were collected from restored and control (without any restoration) areas from Al-Jenebeen (AJ), Queen Rearing Center (QRC), and Shekiran (SK) from depths of 0-60 cm. Results exhibited that sandy loam was the most dominant textural class in all the studied sites $(\sim 60 \%)$, followed by sandy clay loam. All the soils were slightly alkaline and nonsaline. Due to restoration practices, the $\mathrm{pH}$ was increased in AJ and QRC, while decreased in SK areas. With restoration, EC in AJ and QRC sites decreased, but increased in SK. Restoration practices resulted in reduced SOM in AJ and QRC, while increased in SK. Increased SOM in SK may improve floral traits after restoration. Overall, restored SK possessed higher SOM and nutrients with reduced $\mathrm{pH}$, and, hence, could be a potential source for honeybee flora. Further in depth analyses of restoration activities are needed to explore the long term effects on land rehabilitation.
\end{abstract}

Keywords: forest degradation; biodiversity; rehabilitation; soil fertility

\section{Introduction}

Soil/forest degradation is one of the major problems of agricultural soils worldwide [1]. Global soil resources are at risk of degradation due to anthropogenic and natural factors, consequently resulting in lower crop yields [2]. According to some estimates, $33 \%$ of the world land surface has been degraded, resulting in a decline of about $60 \%$ of ecosystem services $[3,4]$. Soil/forest degradation could be elicited by some chemical, physical, biological, and/or ecological processes, which subsequently deteriorate soil quality and fertility [5]. Therefore, soil quality is of significant importance for human health and the environment, due to its significant implication for ecosystems. Consequently, the degradation of soil is disturbing the natural ecological balance, economic growth, and ecosystem sustainability. Therefore, measures must be taken to protect soil quality and restore the degraded lands to enhance ecosystem services such as food, fiber, water filtration, and elemental cycling.

Soil degradation can be evaluated through investigating the chemical, physical, biological, and hydrological characteristics of soil [6,7]. Variations to these properties could disturb the natural ecosystem balance and soil health. The deterioration of soil structure, aggregates, and pore geometry could generate crusts and compaction, consequently enhancing soil erosion, and, thus, are referred to as physical degradation. On the other hand, soil salinization, acidification, toxification, and nutrient loss could reduce soil fertility and 
quality and is thus referred as chemical degradation. Likewise, the loss of organic matter, declined biodiversity, and enhanced greenhouse gas emissions is referred as the biological degradation. According to an estimate, about $85 \%$ of soils have been degraded, globally, due to soil erosion [8]. Therefore, physical degradation is considered as a limiting factor in enhancing crop production and sustaining natural ecosystems. Moreover, physical degradation is the major cause of lower nutrient retention and reduced water holding capacity, especially in arid and semiarid regions of the world. However, soil degradation alone is considered to be counterproductive. Hence, a set of appropriate soil indicators should be selected to identify the problem, which is a challenge to perform in field conditions. In this context, the selection of appropriate soil quality indicators, assessing the soil quality, and sustainable land management strategies are of significant importance for soil protection and sustainable ecosystems.

Forests degradation due to extensive agricultural practices and climate has also resulted in a reduction in biodiversity [9-11]. It has been observed that populations of wild bees are dropping rapidly [12]. Specifically, the decline in populations of pollinators is of great concern nowadays. Therefore, efforts are being made by various researchers to conserve and enhance the populations of the wild bees in order to streamline the pollination process. One of these restoration methods involves the development of floral, woody, and shrub based landscapes in agricultural areas [13]. However, these restoration practices are costly and time consuming, hence, their adoption among growers is very low. Therefore, the restoration of degraded lands on larger scales could serve as an efficient conservation method for sustainable ecosystems and habitat rehabilitation for wild bees. However, the assessment of soil quality and restoration extent is a complex process due to the involvement of various factors, and requires detailed investigations into chemical, physical, and biological characteristics of soil, over time. Hence, keeping in mind all the above mentioned facts, a study was conducted with the objectives (i) to analyze the physical and chemical characteristics of the soil collected from restored and control (without restoration activities) areas in southwest Saudi Arabia (Al-baha Region, Baljurashi district), and (ii) to identify soil nutrient status and soil degradation to understand the major soil related problems/constraints for soil rehabilitation.

\section{Materials and Methods}

\subsection{Study Site Description}

The study was carried out in forests of southwest Saudi Arabia (Al-baha Region, Baljurashi district). The landscape constitutes the remainder of the forest stock of the country [14]. Due to the geographical diversity, this land feature has diverse climates, thus favoring the growth and flowering of greatly diversified bee plant genotypes rich in nectar and pollen, including Acacia species. As a result, most of the beekeeping activities of the country are concentrated in this region. The area is categorized as being mid to high land physiographic and climatic conditions. The humidity ranges from 52-67\%, with rainfall from $229-581 \mathrm{~mm} /$ annum. The mean annual temperature is $22.9^{\circ} \mathrm{C}$. The major land use of the area is characterized by rangeland where free grazing and browsing is a common practice. The rangeland is also comprised of fallow land deserted decades ago.

For current study, 3 areas (Al-Jenebeen (AJ), Queen Rearing Center (QRC), and Shekiran (SK)), where restoration activities have already been practiced, were selected from the study site. The AJ and QRC are relatively flat areas, while the SK is more of hilly landscape. AJ is known for open browsing/grazing land, whereas the QRC and SK possess limited browsing/grazing land in the area despite relatively good plant cover. Similar weather prevails in QRC and SK areas, while AJ differs from these two as it receives less rainfall and is relatively warmer.

\subsection{Restoration Activities}

Despite its relatively good vegetation coverage, the area is severely degraded and only relict woodland patches exist. It was seen that AJ area was relatively more degraded in 
terms of vegetation cover and composition as compared to QRC and SK. These situations are believed to easily motivate stakeholders in the rehabilitation of the vegetation (apicultural landscapes) of the area, for both environmental and economic reasons. Therefore, some restoration activities have been conducted in the area already. These restoration activities include fencing; plantation of local plants, especially acacia species; and installation of drip irrigation systems. The fencing was developed to avoid interferences, trampling, and overgrazing of new sprouts, while plantation of new plants and drip irrigation installation were performed to enhance vegetation cover.

\subsection{Site Profiling and Soil Samples Collection}

The soil samples were taken from both restored and control sites located in study areas, i.e., AJ, QRC, and SK. From both groups, 3 soil profiles were dug and the samples were collected. Soil profiles were created on different localities in the study areas and samples were collected from various depths, i.e., 0-20 cm, 20-40 cm, and 40-60 cm. Additionally, some surface and composite samples were also collected to increase the possibility of analyzing the samples from different angles. Composite samples were created from each soil profile layer for both treatment groups in each site. In this way, a total of 78 samples were collected from all studied areas, comprising of different land use types, soil depths, and localities, as shown in Table 1.

Table 1. Details of the collected samples along with the coordinates of the sampling locations.

\begin{tabular}{|c|c|c|c|c|c|c|c|}
\hline No. & Area & Code & Land Use & Type & No. of Samples & Latitude & Longitude \\
\hline 1 & Al-Jenebeen & AJ-R & Restored & Profile-1 & 3 & 19.86045 & 41.69706 \\
\hline 2 & Al-Jenebeen & AJ-R & Restored & Profile-2 & 3 & 19.86009 & 41.696915 \\
\hline 3 & Al-Jenebeen & AJ-R & Restored & Profile-3 & 3 & 19.86002 & 41.696861 \\
\hline 4 & Al-Jenebeen & AJ-R & Restored & $\begin{array}{l}\text { Composite } \\
\text { and surface }\end{array}$ & 4 & - & - \\
\hline 5 & Al-Jenebeen & $\mathrm{AJ}-\mathrm{C}$ & Control & Profile-1 & 3 & 19.85999 & 41.69712 \\
\hline 6 & Al-Jenebeen & $\mathrm{AJ}-\mathrm{C}$ & Control & Profile-2 & 3 & 19.86037 & 41.69768 \\
\hline 7 & Al-Jenebeen & $\mathrm{AJ}-\mathrm{C}$ & Control & Profile-3 & 3 & 19.85830 & 41.68455 \\
\hline 8 & Al-Jenebeen & $\mathrm{AJ}-\mathrm{C}$ & Control & $\begin{array}{l}\text { Composite } \\
\text { and surface }\end{array}$ & 4 & - & - \\
\hline 9 & Queen Rearing Center & QRC-R & Restored & Profile-1 & 3 & 19.84864 & 41.58691 \\
\hline 10 & Queen Rearing Center & QRC-R & Restored & Profile-2 & 3 & 19.84804 & 41.58657 \\
\hline 11 & Queen Rearing Center & QRC-R & Restored & Profile-3 & 3 & 19.84823 & 41.58625 \\
\hline 12 & Queen Rearing Center & QRC-R & Restored & $\begin{array}{l}\text { Composite } \\
\text { and surface }\end{array}$ & 4 & - & - \\
\hline 13 & Queen Rearing Center & QRC-C & Control & Profile-1 & 3 & 19.84755 & 41.58692 \\
\hline 14 & Queen Rearing Center & QRC-C & Control & Profile-2 & 3 & 19.84808 & 41.58704 \\
\hline 15 & Queen Rearing Center & QRC-C & Control & Profile-3 & 3 & 19.84854 & 41.58651 \\
\hline 16 & Queen Rearing Center & QRC-C & Control & $\begin{array}{l}\text { Composite } \\
\text { and surface }\end{array}$ & 4 & - & - \\
\hline 17 & Shekiran & SK-R & Restored & Profile-1 & 3 & 19.85031 & 41.58733 \\
\hline 18 & Shekiran & SK-R & Restored & Profile-2 & 3 & 19.85037 & 41.58776 \\
\hline 19 & Shekiran & SK-R & Restored & Profile-3 & 3 & 19.85032 & 41.58773 \\
\hline 20 & Shekiran & SK-R & Restored & $\begin{array}{l}\text { Composite } \\
\text { and surface }\end{array}$ & 4 & - & - \\
\hline
\end{tabular}


Table 1. Cont.

\begin{tabular}{cccccccc}
\hline No. & Area & Code & Land Use & Type & No. of Samples & Latitude & Longitude \\
\hline 21 & Shekiran & SK-C & Control & Profile-1 & 3 & 19.84889 & 41.58808 \\
\hline 22 & Shekiran & SK-C & Control & Profile-2 & 3 & 19.84916 & 41.58823 \\
\hline 23 & Shekiran & SK-C & Control & Profile-3 & 3 & 19.84955 & 41.58846 \\
\hline 24 & Shekiran & SK-C & Control & $\begin{array}{c}\text { Composite } \\
\text { and surface }\end{array}$ & 4 & - & - \\
\hline
\end{tabular}

\subsection{Soil Samples Processing and Analyses}

The collected soil samples were brought to the laboratory, air dried, ground, and passed through $2 \mathrm{~mm}$ screen. Thereafter, these samples were subjected to various soil analyses.

\subsubsection{Soil Physiochemical Analyses}

The $\mathrm{pH}$ of the soil was determined in a 1:1 $(w / v)$ ratio suspension of soil to water by using a portable $\mathrm{pH}$ meter ( $\mathrm{pH} 315 \mathrm{i}, \mathrm{WTW}$, Germany). Likewise, the filtrate of 1:1 suspension was used to analyze soil electrical conductivity (EC) by using a conductivity meter (EC meter: 4510, Jenway, UK). Cations and anions of the soil were measured by using the standard procedures, as reported earlier by [15]. Soil particle size distribution was determined by using the hydrometer method, while the texture was determined with the help of United States Department of Agriculture's textural triangle for soil taxonomy [16]. The soils collected from the study area belong to lithosols and yermosols types. The contents of calcite $\left(\mathrm{CaCO}_{3}\right)$ in collected samples were analyzed through calcimeter method [17]. Briefly, $2.0 \mathrm{~g}$ of soil was reacted with $0.1 \mathrm{~N}$ hydrochloric acid $(\mathrm{HCl})$ under an airtight environment and the evolved $\mathrm{CO}_{2}$ was measured. Then, calcite percentage was determined through comparing the emission of $\mathrm{CO}_{2}$ from the sample with that of pure $\mathrm{CaCO}_{3}$. Soil organic matter was detected by following Walkley and Black (1934) method [18]. Briefly, $0.5 \mathrm{~g}$ soil was taken in round neck flask. Then, $10 \mathrm{~mL}$ of $1 \mathrm{~N}$ potassium dichromate solution was added, followed by $20 \mathrm{~mL}$ concentrated sulfuric acid. Sample was allowed to stand for $30 \mathrm{~min}$. Later, $200 \mathrm{~mL}$ of distilled water was added to the sample followed by 3-4 drops of diphenylamine indicator. Sample was titrated with $0.5 \mathrm{M}$ ferrous ammonium sulfate solution until the color changed from violet-blue to reddish brown. Additionally, a blank sample was run without soil sample.

\subsubsection{Available Nutrients Analyses}

Plant available phosphorus $(\mathrm{P})$ and micronutrients, i.e., copper $(\mathrm{Cu})$, iron $(\mathrm{Fe})$, zinc $(\mathrm{Zn})$, and manganese (Mn), in soil were extracted using AB-DTPA (ammonium bicarbonatediethylenetriaminepentaacetic acid) extraction method [19]. Briefly, a mixture of $1 \mathrm{M}$ ammonium bicarbonate and $0.005 \mathrm{M}$ DTPA with $\mathrm{pH}$ of 7.6 was used to extract $\mathrm{P}$ and micronutrients through 1:2 soil-AB-DTPA ( $w / v$ ratio) suspension. The concentration of $\mathrm{K}$ in the soil samples was analyzed by using flame photometer. The concentration of P in AB-DTPA extract was measured through colorimetry method by using UV/VIS spectrophotometer (Lambda EZ 150, PerkinElmer, Norwalk, CT, USA). The contents of micronutrients in AB-DTPA extract were determined by using Inductivity coupled plasma optical emission spectrophotometer (ICP-OES, PerkinElmer Optima 4300 DV, Akron, OH, USA).

\subsection{Data Analyses and Statistics}

The soil analyses data were statistically analyzed by using Microsoft Excel and Statistics 8.01 program. Descriptive statistics was used to calculate minimum, maximum, mean, skewness, kurtosis, and coefficient of variation (CV) of the data. Pearson correlations were calculated to explore the relation of various soil properties and nutrients concentrations with each other. 


\section{Results and Discussion}

\subsection{Soil Physiochemical Properties as Indicators for Degradation and Restoration}

\subsubsection{Soil Texture}

The variations in soil texture of the different soil samples collected from the control and restored areas of the studied sites are shown in Figure 1. The results exhibited that sandy loam was the most dominant textural class in all the studied sites $(\sim 60 \%)$, followed by sandy clay loam. Overall, QRC has more samples in the sandy loam textural class, followed by SK and AJ. The loamy sand class was present in QRC-C, QRC-R, and SK-C, while absent in other collected samples.

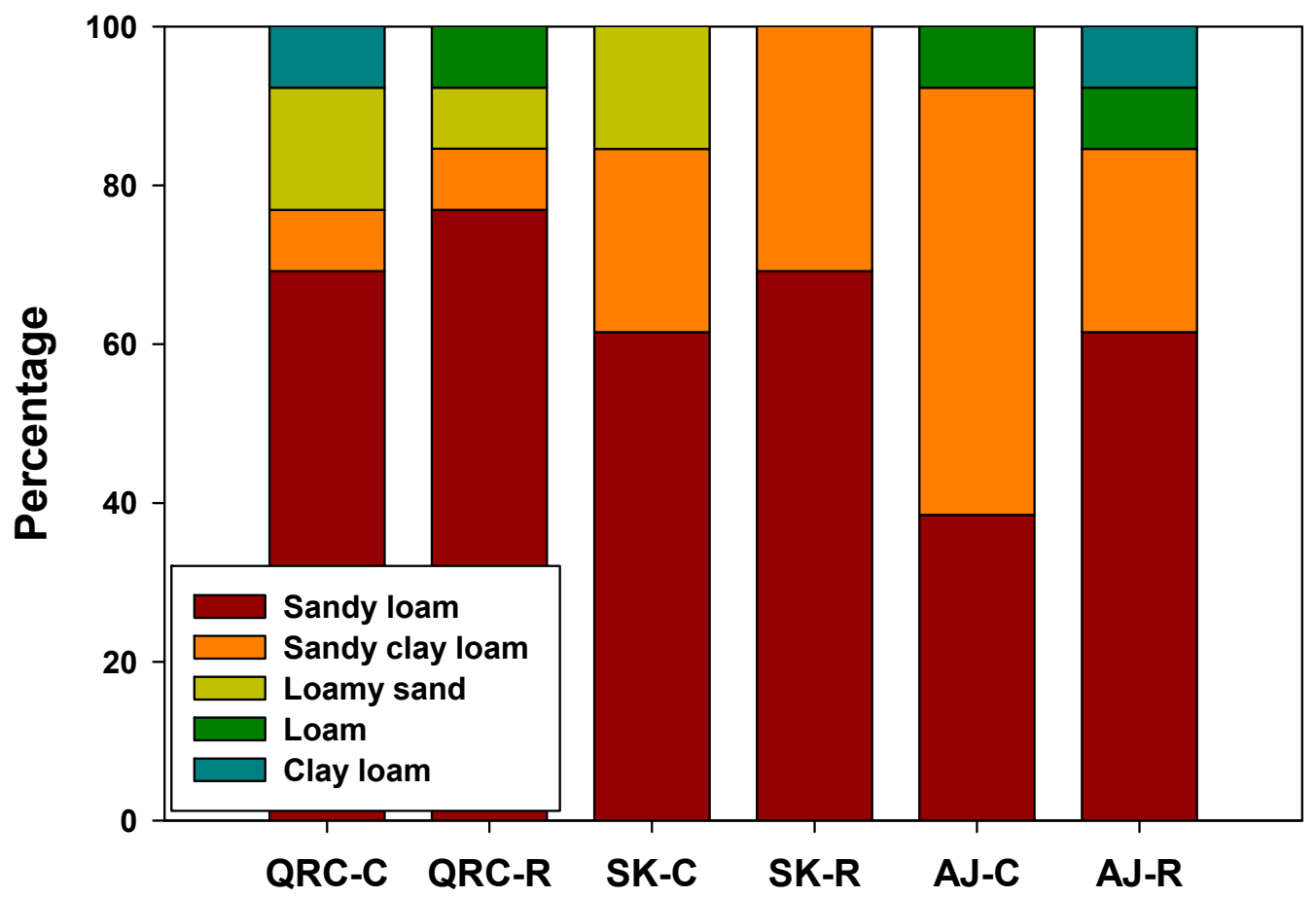

Figure 1. Proportion of various textural classes in the soil samples collected from different localities in southwestern Saudi Arabia (QRC-C: Queen Rearing Center Control, QRC-R: Queen Rearing Center Restored, SK-C: Shekiran control, SK-R: Shekiran Restored, AJ-C: Al-Jenebeen Control, and AJ-R: Al-Jenebeen Restored).

Likewise, loam can be seen only in QRC-R, AJ-C, and AJ-R, whereas clay loam was present only in QRC-C and AJ-R. It was interesting to notice that the proportion of sandy loam soils was higher in restored areas as compared to the control areas. The restored areas of QRC showed the occurrence of loam soil, which was not present in the control areas. Likewise, clay loam soils were seen in the control of QRC, and absent in its restored areas. The control areas of SK had about $16 \%$ samples of loamy sand, which disappeared in restored areas. Similarly, clay loam soils were seen in restored areas of AJ, while these were absent in AJ-C. Therefore, variations in control and restored areas evidenced the effects of restoration efforts on the physical properties of the soils in the studied area. Owing to the significant importance of soil texture, various researchers have used it as an indicator for assessing soil quality $[20,21]$. Various agricultural practices, especially tillage and plowing, could affect the texture of soils. Likewise, natural processes, as well as irrigation, could move the clays downward and may result in their accumulation in deep soil horizons, subsequently changing the proportions of sand, silt, and clay. Therefore, soil texture is an important parameter to investigate soil type and quality [1,22]. The predominance of sand based texture indicated lower water holding capacity, poor soil structure, and lower nutrient retention. QRC-C and AJ-R possess relatively higher contents of clay, indicating a slightly better soil structure as compared to the rest of the soil types. Therefore, these 
changes in the distribution of silt, clay, and sand fractions, along with changing the land-use type and locality, indicated the difference in erosion and sedimentation rates.

\subsubsection{Soil $\mathrm{pH}$ and $\mathrm{EC}$}

Soil $\mathrm{pH}$ plays a critical role in the dissolution and availability of nutrients as well as for proper microbial activities in soil. Similarly, soil EC is an important factor for plant nutrient availability and optimum crop growth. Therefore, soil $\mathrm{pH}$ and EC are considered important indicators to assess the extent of soil quality. The descriptive statistical analyses for $\mathrm{pH}$ and EC of the collected soil samples are shown in Table 2. It can be seen that all the soils were slightly alkaline, with a mean $\mathrm{pH}$ range of 7.74 to 8.15 . Overall, the mean $\mathrm{pH}$ values of $\mathrm{AJ}$ were higher (8.07-8.15), followed by SK (7.81-8.01) and QRC (7.74-7.99). Results showed that means increased from 8.07 in the control to 8.15 in restored areas and 7.74 in the control to 7.99 in restored areas in $\mathrm{AJ}$ and QRC, respectively, whereas, it decreased from 8.01 in the control to 7.81 in restored areas in SK. The increment in soil $\mathrm{pH}$ due to restoration processes could be due to the release of saline products by the plant's branches and leaves, as more plants were grown during restoration [23]. Additionally, the recycling of some organic components during the restoration process might have enhanced the soil $\mathrm{pH}$. Contrarily, the $\mathrm{pH}$ of restored areas located in SK sites decreased to 7.81 from 8.01 in the control. This decrease in $\mathrm{pH}$ could be caused by the addition and mineralization of organic compounds due to restoration activities [24]. This reduction in $\mathrm{pH}$ in SK areas after restoration could help in enhancing vegetation growth, which, in turn, could increase floral resources for honeybees. Furthermore, the decrease in $\mathrm{pH}$ could be owing to the uptake of exchangeable cations by plant or microorganisms in soil. The degree of variability, as indicated by CV values, was in the range of 1.99 to 3.75 . All the $\mathrm{pH}$ data was well skewed with lower kurtosis $(-1.438--0.041)$, indicating a normal distribution. The differences in $\mathrm{pH}$ values were statistically significant, except for QRC-R and SK-C which were nonsignificantly different. The $\mathrm{pH}$ for AJ-R was significantly higher (8.15) as compared to all the other samples. Similarly, significant differences were also seen in EC results, where AJ-C showed the highest value $\left(0.45 \mathrm{dS} \mathrm{m}^{-1}\right)$.

The influence of soil depth on variations in soil pH can be seen in Figure 2A,C,E. Overall, the mean $\mathrm{pH}$ values of restored areas were higher than that of the controls for all three sites. However, this was the opposite in the topsoil of QRC and SK, where restored areas had lower $\mathrm{pH}$ values than the control areas. The trend for distribution of the soil $\mathrm{pH}$ with depth was not uniform. For instance, the mean $\mathrm{pH}$ values increased with increasing the depth in AJ-C, while it decreased with depth in QRC-C and SK-C. Meanwhile, this was exactly the opposite in restored areas, where mean $\mathrm{pH}$ values decreased with depth in AJ-R, and increased in QRC-R and SK-R. Similar contrasting results were also reported by different researchers. For example, a decrease in soil $\mathrm{pH}$ with an increase in soil depth was previously reported by Shukla et al. [25], whereas Zhang et al. [26] reported an increase in soil $\mathrm{pH}$ with an increase in the depth, suggesting that this could be due to the addition of organic amendments in the soil. Overall, the results indicated that the effects of soil depth on variations in soil $\mathrm{pH}$ were not significant.

Table 2 showed that the mean EC values for all the soil samples were in the range of 0.34 to $0.45 \mathrm{dS} \mathrm{m} \mathrm{m}^{-1}$, suggesting that EC for all the soil samples was below salinity limits, i.e., $4 \mathrm{dS} \mathrm{m}^{-1}$ [27]. Overall, the samples collected from AJ sites had higher EC values, followed by QRC, and SK. The results exhibited that the EC of the AJ and QRC sites reduced after restoration activities, from 0.45 to $0.36 \mathrm{dS} \mathrm{m}^{-1}$ and 0.43 to $0.38 \mathrm{dS} \mathrm{m}^{-1}$, respectively, whereas, it increased in the case of SK, from 0.34 to $0.40 \mathrm{dS} \mathrm{m}^{-1}$. The increase in soil EC could be the result of adding organic matter during restoration activities, while the reduction in EC clearly indicated the significant role of plantation on soil quality [28]. The values of the skewness and kurtosis showed that the distribution was not normal. Figure 2B,D,F shows variations in mean EC with soil depth. The EC values reduced with an increase in soil depth in AJ-C, while increasing with an increase in soil depth in QRC-C and SK-C. This trend was opposite in restored areas, where EC increased with soil depth in the 
case of AJ-R, and decreased with depth in QRC-R and SK-R. Bezborodov et al. [29] stated that EC increases with soil depth due to the presence of salts. Therefore, the distribution and extent of soil $\mathrm{pH}$ and EC can effectively be used as indicators for assessing soil degradation and restoration.

Table 2. Descriptive statistics of the $\mathrm{pH}$ and EC data of soil samples collected from Al-Jenebeen (AJ), Queen Rearing Center (QRC), and Shekiran (SK) in southwestern Saudi Arabia.

\begin{tabular}{|c|c|c|c|c|c|c|c|c|c|c|}
\hline Parameter & Location & Land Use & Mean & Median & Min. & Max. & SD & $\mathrm{CV}$ & Skew & Kurtosis \\
\hline \multirow{6}{*}{$\mathrm{pH}$} & \multirow{2}{*}{$\mathrm{AJ}$} & $\begin{array}{l}\text { Control } \\
(n=13)\end{array}$ & 8.07 & 8.03 & 7.82 & 8.27 & 1.16 & 1.99 & -0.092 & -1.438 \\
\hline & & $\begin{array}{l}\text { Restored } \\
(n=13)\end{array}$ & 8.15 & 8.24 & 7.87 & 8.31 & 0.67 & 2.07 & -0.993 & -0.718 \\
\hline & \multirow{2}{*}{ QRC } & $\begin{array}{l}\text { Control } \\
(n=13)\end{array}$ & 7.74 & 7.70 & 7.28 & 8.25 & 0.29 & 3.75 & 0.406 & -0.622 \\
\hline & & $\begin{array}{l}\text { Restored } \\
(n=13)\end{array}$ & 7.99 & 8.02 & 7.60 & 8.29 & 0.21 & 2.63 & -0.619 & -0.646 \\
\hline & \multirow{2}{*}{ SK } & $\begin{array}{l}\text { Control } \\
(n=13)\end{array}$ & 8.01 & 7.96 & 7.81 & 8.36 & 0.18 & 2.23 & 0.914 & -0.303 \\
\hline & & $\begin{array}{l}\text { Restored } \\
(n=13)\end{array}$ & 7.81 & 7.82 & 7.39 & 8.07 & 0.2 & 2.51 & -0.678 & -0.041 \\
\hline \multirow{6}{*}{$\mathrm{EC}\left(\mathrm{dS} \mathrm{m}^{-1}\right)$} & \multirow{2}{*}{$\mathrm{AJ}$} & $\begin{array}{l}\text { Control } \\
(n=13)\end{array}$ & 0.45 & 0.39 & 0.24 & 1.18 & 0.25 & 56.57 & 2.015 & 3.602 \\
\hline & & $\begin{array}{c}\text { Restored } \\
(n=13)\end{array}$ & 0.36 & 0.30 & 0.20 & 1.09 & 0.24 & 64.64 & 2.450 & 5.181 \\
\hline & \multirow{2}{*}{ QRC } & $\begin{array}{l}\text { Control } \\
(n=13)\end{array}$ & 0.43 & 0.48 & 0.20 & 0.60 & 0.14 & 31.25 & -0.503 & -1.103 \\
\hline & & $\begin{array}{l}\text { Restored } \\
(n=13)\end{array}$ & 0.38 & 0.37 & 0.19 & 0.55 & 0.11 & 28.34 & -0.013 & -0.971 \\
\hline & \multirow{2}{*}{ SK } & $\begin{array}{l}\text { Control } \\
(n=13)\end{array}$ & 0.34 & 0.31 & 0.24 & 0.56 & 0.09 & 26.97 & 1.026 & 0.666 \\
\hline & & $\begin{array}{c}\text { Restored } \\
(n=13)\end{array}$ & 0.40 & 0.36 & 0.24 & 0.60 & 0.13 & 32.46 & 0.305 & -1.423 \\
\hline
\end{tabular}

\subsubsection{Soil Organic Matter, Soil Organic Carbon, and $\mathrm{CaCO}_{3}$}

Soil organic matter (SOM) significantly influences the chemical, physical, and biological characteristics of soils [30]. It has been well documented that the depletion of SOM as a result of extensive agricultural practices has subsequently resulted in soil degradation [31,32]. Therefore, SOM is considered as one of the most promising and sensitive factors in assessing soil quality and the extent of its degradation. The descriptive statistical analyses for SOM for the samples collected from selected localities are shown in Table 3. Overall, the mean values of the contents of SOM were lower than $1.5 \%$ in all the locations. The samples collected from SK sites possessed higher SOM $(0.13-2.56 \%)$, as compared to AJ $(0.25-2.19 \%)$, and QRC (0.13-1.89\%). It was noticed that the restoration practices resulted in reduced SOM in $\mathrm{AJ}(1.27 \%$ in $\mathrm{AJ}-\mathrm{C}$ to $1.02 \%$ in $\mathrm{AJ}-\mathrm{R})$ and QRC $(0.88 \%$ in QRC-C to $0.80 \%$ in QRC-R), while it increased with restoration practices in SK (1.16\% in SK-C to $1.40 \%$ in SK-R). This data showed a higher variability, as shown with larger CV values (27.24-68.40). The skewness of the data was in the range of -0.316 to 0.244 , while kurtosis was -1.326 to -0.304 , indicating normality in the distribution of the data. Further, the changes in the contents of SOM with soil depth are shown in Figure 3A,C,E. The variations in SOM contents with soil depth were inconsistent. For instance, the mean SOM contents increased with an increase in soil depth in AJ-C and SK-R, while reducing with soil depth in the rest of the studied soil profiles. Interestingly, the topsoil of SK (both restored and the control) and AJ-C showed relatively lower SOM contents. 

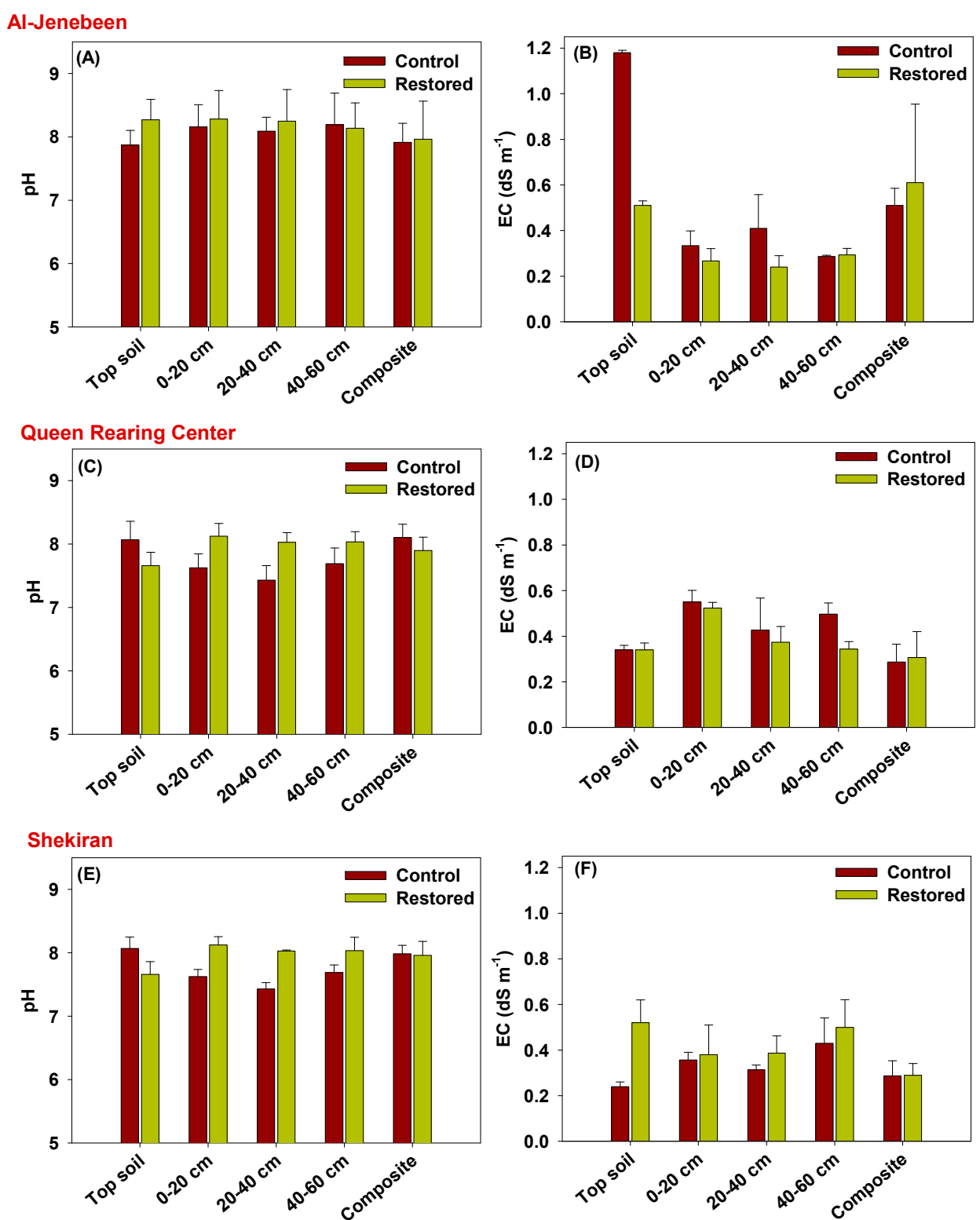

Figure 2. Variations in mean $\mathrm{pH}$ and electrical conductivity (EC) with soil depth for the samples collected from different localities in southwestern Saudi Arabia ((A): $\mathrm{pH}$ and (B): EC in Al-Jenebeen, (C): $\mathrm{pH}$ and (D): EC in Queen Rearing Center, and (E): $\mathrm{pH}$ and (F): EC in Shekiran). The error bars represent the standard deviations of the mean values.

The variations in SOM of the collected soil samples suggested that restoration activities had positive impacts on soil rehabilitation in SK sites, as indicated by increased SOM contents. Contrarily, the SOM contents of AJ and QRC sites reduced as a result of restoration activities. The loss of SOM during restoration activities could be due to higher sand fractions. Generally, the SOM associated with clay fractions is more resistant to degradation. However, our study demonstrated that sandy loam was the most dominant textural class for all the collected samples, indicating a higher portion of sand [33]. Kalinina et al. [34] suggested that the loss of SOM could also be due to higher humus rich arable soils, texture, and mowing. To further understand this, the proportions of soil organic carbon (SOC), according to the soil evaluation criteria, are presented in Figure 4 . It can be seen in the figure that none of the samples were in the ranges of high, very high and extremely high SOC contents. Most of the samples were in the extremely low to moderate SOC range. The proportion of samples with moderate SOC contents was higher after restoration in 
the SK area, while it was reduced to zero in both $\mathrm{AJ}$ and QRC after restoration. On the other hand, the samples with moderately low SOC contents increased in AJ and QRC, while reducing in SK after restoration activities. This clearly indicates the loss of SOC and SOM from the soil after restoration activities. It is well known that plants cannot absorb $\mathrm{SOM} / \mathrm{SOC}$ from the soil, rather, SOC helps plants to uptake nutrients in soil by altering physical, chemical and biological conditions [35]. However, the mineralization of SOM may release nutrients into the soil solution for the plants to uptake; hence, it is an important factor to assess soil fertility. Moreover, SOM is of significant importance for soil structure, aggregate stability, and clay dispersibility [36]. However, the cultivation of crops may disturb larger aggregates, resulting in enhanced SOM degradation. The plantation of local plants might have resulted in the loss of organic matter contents, which can deteriorate soil health and structure. Therefore, SOM needs to be maintained for the sustainable growth and development of the planted plants, so they can be used by honeybees. A recent study demonstrated that the application of SOM enhanced the visitation of bumblebee, as compared to without SOM application [37]. In another study, it was observed that higher SOM attracted 185 pollinators, as compared to 132 pollinators attracted by the soils with lower SOM [38]. This could possibly be due to the release of micro- and macronutrients from SOM mineralization, which improve the quality of flowers via increasing sugar contents and flower longevity, consequently attracting the pollinators towards them.

Table 3. Descriptive statistics for soil organic matter (SOM) and $\mathrm{CaCO}_{3}$ of the soil samples collected from Al-Jenebeen (AJ), Queen Rearing Center (QRC), and Shekiran (SK) in southwestern Saudi Arabia.

\begin{tabular}{|c|c|c|c|c|c|c|c|c|c|c|}
\hline Parameter & Location & Land Use & Mean & Median & Min. & Max. & SD & $\mathrm{CV}$ & Skew & Kurtosis \\
\hline \multirow{6}{*}{ SOM $(\%)$} & \multirow{2}{*}{$\mathrm{AJ}$} & $\begin{array}{l}\text { Control } \\
(n=13)\end{array}$ & 1.27 & 1.13 & 0.25 & 2.19 & 0.55 & 43.47 & 0.183 & -0.304 \\
\hline & & $\begin{array}{l}\text { Restored } \\
(n=13)\end{array}$ & 1.02 & 0.96 & 0.56 & 1.46 & 0.28 & 27.24 & 0.242 & -1.007 \\
\hline & \multirow{2}{*}{ QRC } & $\begin{array}{l}\text { Control } \\
(n=13)\end{array}$ & 0.88 & 0.63 & 0.13 & 1.89 & 0.60 & 68.40 & 0.244 & -1.326 \\
\hline & & $\begin{array}{c}\text { Restored } \\
(n=13)\end{array}$ & 0.80 & 0.83 & 0.26 & 1.32 & 0.30 & 37.25 & -0.214 & -0.556 \\
\hline & \multirow[b]{2}{*}{ SK } & $\begin{array}{l}\text { Control } \\
(n=13)\end{array}$ & 1.16 & 1.21 & 0.53 & 1.78 & 0.39 & 33.99 & -0.059 & -1.212 \\
\hline & & $\begin{array}{c}\text { Restored } \\
(n=13)\end{array}$ & 1.40 & 1.53 & 0.13 & 2.56 & 0.66 & 46.83 & -0.361 & -0.375 \\
\hline \multirow{6}{*}{$\mathrm{CaCO}_{3}(\%)$} & \multirow{2}{*}{$\mathrm{AJ}$} & $\begin{array}{l}\text { Control } \\
(n=13)\end{array}$ & 0.62 & 0.48 & 0.52 & 1.52 & 0.00 & 83.89 & 0.533 & -0.910 \\
\hline & & $\begin{array}{c}\text { Restored } \\
(n=13)\end{array}$ & 0.35 & 0.30 & 0.25 & 0.96 & 0.04 & 73.07 & 0.886 & 0.460 \\
\hline & \multirow{2}{*}{ QRC } & $\begin{array}{l}\text { Control } \\
(n=13)\end{array}$ & 0.52 & 0.26 & 0.62 & 2.22 & 0.04 & 120.55 & 1.777 & 2.279 \\
\hline & & $\begin{array}{l}\text { Restored } \\
(n=13)\end{array}$ & 0.78 & 0.35 & 0.79 & 2.39 & 0.00 & 101.47 & 0.898 & -0.699 \\
\hline & \multirow{2}{*}{ SK } & $\begin{array}{l}\text { Control } \\
(n=13)\end{array}$ & 0.39 & 0.30 & 0.41 & 1.39 & 0.00 & 105.51 & 1.123 & 0.570 \\
\hline & & $\begin{array}{c}\text { Restored } \\
(n=13)\end{array}$ & 0.57 & 0.26 & 0.70 & 1.96 & 0.00 & 122.70 & 1.039 & -0.521 \\
\hline
\end{tabular}



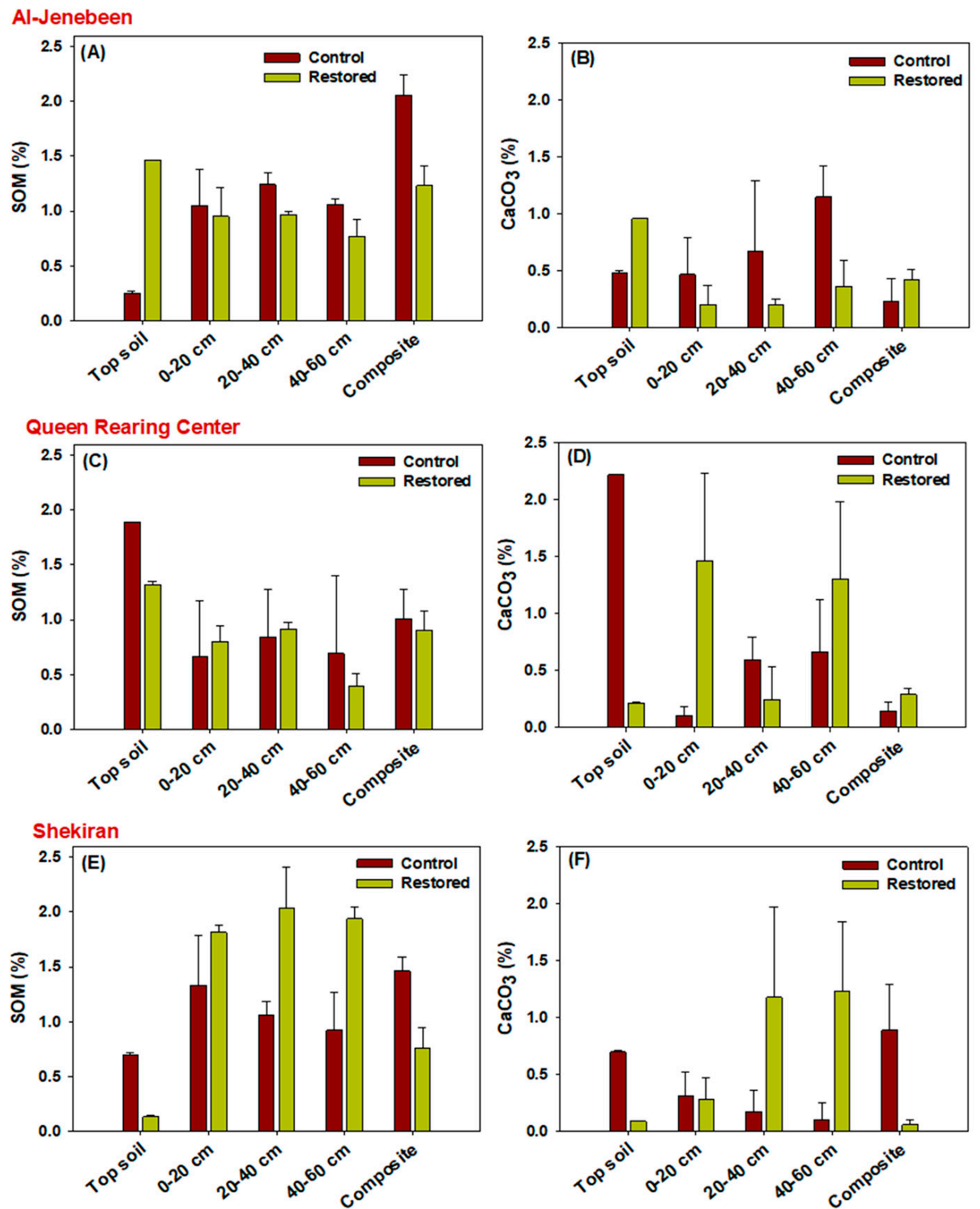

Figure 3. Variations in mean soil organic matter (SOM) contents and $\mathrm{CaCO}_{3}$ with soil depth for the samples collected from different localities in southwestern Saudi Arabia ((A): SOM and (B): $\mathrm{CaCO}_{3}$ in Al-Jenebeen, (C): SOM and (D): $\mathrm{CaCO}_{3}$ in Queen Rearing Center, and (E): SOM and (F): $\mathrm{CaCO}_{3}$ in Shekiran). The error bars represent the standard deviations of the mean values.

Nevertheless, due to the fact that SOC is sensitive to various factors, such as agricultural practices, climate, minerals in the soil, topography, and microbial communities, there is a higher spatial and temporal variability in its contents. This makes it difficult to compare the SOC of different sites, despite its extreme importance for soil quality topography [39]. Overall, SK sites have shown the better results of land restoration practices, as compared to QRC and AJ. The retention of SOC in the SK area, as compared to AJ and QRC, could be due to the difference in various factors, such as altitude, slope gradient, and $\mathrm{pH}$. It has been reported that altitude has a significant effect on SOC retention in [40]. SK was a hilly area with a relatively higher altitude, thus, the development of various microhabitats might have facilitated the growth of plant communities, subsequently accumulating the higher $\mathrm{C}$ contents [41]. Additionally, the chances of aboveground biomass removal are more at lower altitudes than at higher altitudes. Thus, besides other factors, the higher altitude of SK facilitated the retention of SOC in that area after restoration activities. Therefore, loss of 
SOC in AJ and QRC during the restoration process in the current study reflects the poor SOC accumulation ability of the soil, and lower nutrient retention due to the sand based soil texture. Hence, complete restoration of these poor textured sites would require longer periods of time under sustainable practices.

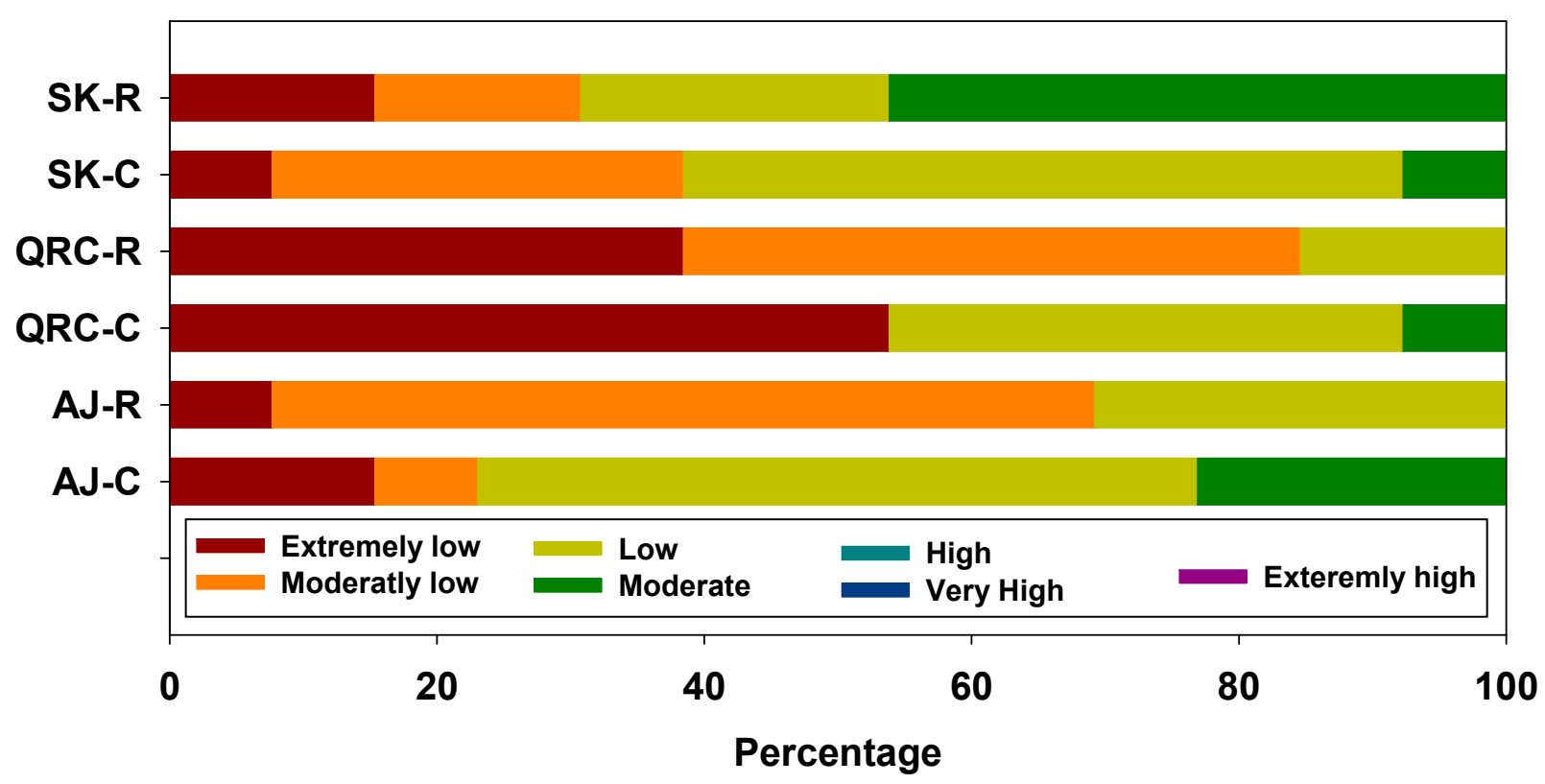

Figure 4. Proportions of soil organic carbon according to the soil quality evaluation criteria for the samples collected from different localities in southwestern Saudi Arabia (QRC-C: Queen Rearing Center Control, QRC-R: Queen Rearing Center Restored, SK-C: Shekiran control, SK-R: Shekiran Restored, AJ-C: Al-Jenebeen Control, and AJ-R: Al-Jenebeen Restored). The used criteria are: extremely low $=<0.4 \%$, moderately low $=0.4-0.59 \%$, low $=0.6-0.99 \%$, moderate $=1-1.59 \%$, high $=1.6-1.99 \%$, very high $=2-2.99 \%$, and extremely high $=>3 \%$ (Hazelton and Murphy, 2007).

The descriptive statistical analyses for the $\mathrm{CaCO}_{3}$ of the collected soil samples are shown in Table 3 . The mean $\mathrm{CaCO}_{3}$ contents were in the range of $0.35 \%$ to $0.78 \%$, suggesting the soils were not calcareous. It was noticed that $\mathrm{CaCO}_{3}$ content reduced from $0.62 \%$ in the control to $0.35 \%$ in restored areas in the $\mathrm{AJ}$ sites, whereas the $\mathrm{CaCO}_{3}$ contents increased from $0.52 \%$ and $0.39 \%$ in the control to $0.78 \%$ and $0.57 \%$ in restored areas in the QRC and $\mathrm{SK}$ sites, respectively. The lower $\mathrm{CV}$ values showed that there was little variability in the data. Likewise, the data was normal, as indicated by the values of skewness (0.533-1.777) and kurtosis (-0.910-2.279). The variations in $\mathrm{CaCO}_{3}$ content with soil depth, as shown in Figure 3, demonstrated different trends. The $\mathrm{CaCO}_{3}$ content increased with an increase in soil depth in AJ-C, while decreasing in QRC-C and SK-C. On contrary, the $\mathrm{CaCO}_{3}$ content decreased with soil depth in AJ-R, whereas it increased in the QRC-R and SK-R areas. As $\mathrm{CaCO}_{3}$ has a significant role in the stabilization of soil aggregates and SOC, the higher $\mathrm{CaCO}_{3}$ contents in the QRC-R and SK-R sites showed the positive impacts of restoration activities. Our results are in agreement with those reported by Rowley et al. [42]. However, the elevated $\mathrm{CaCO}_{3}$ contents in soils may increase the $\mathrm{pH}$, subsequently hindering plant growth.

\subsection{Soil Nutrient Contents as Indicators for Degradation and Restoration \\ 3.2.1. Phosphorus and Potassium}

The descriptive analyses for available $\mathrm{P}$ and $\mathrm{K}$ in the collected soil samples are shown in Table 4. The mean P concentration in all the samples ranged from 1.09 to $2.57 \mathrm{mg} \mathrm{kg}^{-1}$, suggesting poor soil fertility. The mean P concentrations in AJ and QRC are comparable, whereas, the mean $\mathrm{P}$ concentrations were lower in the SK sites. There was a huge variability in the data, as suggested by the larger CV values (72.55-112.36). However, the 
values of the skewness $(-0.115-1.788)$ and kurtosis $(-1.560-2.917)$ indicated normality in the data. The variations in mean $\mathrm{P}$ concentrations due to restoration activities were inconsistent. It was noticed that the mean $P$ concentrations reduced from $2.27 \mathrm{mg} \mathrm{kg}^{-1}$ in the control to $1.21 \mathrm{mg} \mathrm{kg}^{-1}$ in restored areas in AJ. However, $\mathrm{P}$ concentrations increased from $1.09 \mathrm{mg} \mathrm{kg}^{-1}$ in the control to $2.57 \mathrm{mg} \mathrm{kg}^{-1}$ in restored areas in QRC, whereas a very slight decrease ( 0.02 units) was observed in the case of SK, due to the restoration process. The overall decline in available $\mathrm{P}$ in $\mathrm{AJ}$ and SK, due to restoration, could be due to the conversion of soil texture to sandy loam and variations in vegetation composition [43]. Whereas, the increased $\mathrm{P}$ concentrations in QRC after restoration was probably due to the mineralization of soil nutrients, variations in microbial composition and activities [44,45], as well as an uptake in nutrient uptake by plants [46]. Soil P is affected by the parent material, land-use type, and other biological as well as chemical processes, therefore, variations in these properties could result in different $P$ retention in soil [47]. The variations in available $\mathrm{P}$ concentrations with soil depth are represented in Figure 5A,C,F. The highest $\mathrm{P}$ concentration was found in the $0-20 \mathrm{~cm}$ deep soil layer, as compared to the topsoil and deeper soil layers in AJ-C, AJ-R, and SK-C, while the other soil samples showed a decrease in $P$ concentration with soil depth up to $40 \mathrm{~cm}$, and then increases up to $60 \mathrm{~cm}$. Similar results were also reported by $\mathrm{Xu}$ et al. [47], stating that $>60 \%$ of the total $\mathrm{P}$ was detected in the upper soil layer. Moreover, the surface soil is largely influenced by climatic factors, microbial activities, and plant litter accumulation, which result in higher nutrient retention [48].

The descriptive analysis for available soil $\mathrm{K}$ showed a larger variability in the data $(\mathrm{CV}=52.96-104.21)$, with a range of $33.23 \mathrm{mg} \mathrm{kg}^{-1}$ to $81.26 \mathrm{mg} \mathrm{kg}^{-1}$. It can be seen that the restoration activities resulted in an increment in available $\mathrm{K}$ concentrations. The $\mathrm{K}$ concertation was $56.36 \mathrm{mg} \mathrm{kg}^{-1}$ in the control of the AJ site, which increased to $75.58 \mathrm{mg} \mathrm{kg}^{-1}$ in restored areas. Likewise, it increased from $33.23 \mathrm{mg} \mathrm{kg}^{-1}$ in the control to $81.26 \mathrm{mg} \mathrm{kg}^{-1}$ in restored areas in the QRC sites, while no significant change was observed in the SK sites after restoration. The improved $\mathrm{K}$ in soil in all the restored areas could be due to the changes in soil structure and addition of fertilizers [39]. The variations in mean $\mathrm{K}$ concentrations with soil depth are shown in Figure 5B,D,F. The mean K concentrations did not follow any specific trend. For example, $K$ concentration increased to the highest value ( $85.33 \mathrm{mg} \mathrm{kg}^{-1}$ ) in the $0-20 \mathrm{~cm}$ layer, decreased to $24.46 \mathrm{mg} \mathrm{kg}^{-1}$ in the $20-40 \mathrm{~cm}$ layer, and then increased to $54.13 \mathrm{mg} \mathrm{kg}^{-1}$ in the $40-60 \mathrm{~cm}$ layer, in AJ-C. A similar trend was seen in AJ-R and SK-C, while an opposite trend was observed in QRC-C and QRC-R. Therefore, these variations in $\mathrm{P}$ and $\mathrm{K}$ concentrations in soil with restoration activities could be due to the accumulation of organic compounds and the cultivation of plants [49]. However, in depth data is required to investigate the long term effects of the restoration activities.

\subsubsection{Soil Micronutrients}

The descriptive statistical analyses for the available soil micronutrients $(\mathrm{Cu}, \mathrm{Fe}, \mathrm{Zn}$, and $\mathrm{Mn}$ ) are shown in Table 5. Overall, the concentration of Fe was higher in all the soil types, followed by $\mathrm{Mn}, \mathrm{Cu}$, and $\mathrm{Zn}$. The estimated $\mathrm{CV}$ values indicated a higher variability in the concentration of all the micronutrients, whereas the values of skewness and kurtosis suggested normality in the data. The effects of the restoration activities on micronutrients concentrations were not clear. 
Table 4. Descriptive statistics for phosphorus (P) and potassium (K) concentrations of the soil samples collected from Al-Jenebeen (AJ), Queen Rearing Center (QRC), and Shekiran (SK) in southwestern Saudi Arabia.

\begin{tabular}{|c|c|c|c|c|c|c|c|c|c|c|}
\hline Parameter & Location & Land Use & Mean & Median & Min. & Max. & SD & $\mathrm{CV}$ & Skew & Kurtosis \\
\hline \multirow{6}{*}{$\mathrm{P}\left(\mathrm{mg} \mathrm{kg}^{-1}\right)$} & \multirow{2}{*}{$\mathrm{AJ}$} & $\begin{array}{l}\text { Control } \\
(n=13)\end{array}$ & 2.27 & 1.65 & 0.04 & 9.46 & 2.55 & 112.36 & 1.788 & 2.917 \\
\hline & & $\begin{array}{l}\text { Restored } \\
(n=13)\end{array}$ & 1.21 & 1.56 & 0.04 & 2.57 & 0.93 & 76.50 & -0.115 & -1.560 \\
\hline & \multirow{2}{*}{ QRC } & $\begin{array}{l}\text { Control } \\
(n=13)\end{array}$ & 1.09 & 0.28 & 0.11 & 3.49 & 1.21 & 111.12 & 0.907 & -0.726 \\
\hline & & $\begin{array}{l}\text { Restored } \\
(n=13)\end{array}$ & 2.57 & 2.57 & 0.04 & 6.24 & 1.97 & 76.78 & 0.172 & -0.916 \\
\hline & \multirow{2}{*}{ SK } & $\begin{array}{l}\text { Control } \\
(n=13)\end{array}$ & 1.82 & 1.65 & 0.04 & 3.49 & 1.32 & 72.55 & -0.014 & -1.448 \\
\hline & & $\begin{array}{c}\text { Restored } \\
(n=13)\end{array}$ & 1.80 & 1.19 & 0.04 & 6.24 & 1.72 & 95.77 & 1.303 & 1.347 \\
\hline \multirow{6}{*}{$\mathrm{K}\left(\mathrm{mg} \mathrm{kg}^{-1}\right)$} & \multirow{2}{*}{$\mathrm{AJ}$} & $\begin{array}{l}\text { Control } \\
(n=13)\end{array}$ & 56.36 & 31.00 & 11.20 & 210 & 56.72 & 100.63 & 1.645 & 2.065 \\
\hline & & $\begin{array}{l}\text { Restored } \\
(n=13)\end{array}$ & 75.58 & 43.00 & 12.00 & 208 & 67.45 & 89.24 & 1.106 & -0.332 \\
\hline & \multirow{2}{*}{ QRC } & $\begin{array}{l}\text { Control } \\
(n=13)\end{array}$ & 33.23 & 27.60 & 9.40 & 70.20 & 17.59 & 52.96 & 0.623 & -0.410 \\
\hline & & $\begin{array}{l}\text { Restored } \\
(n=13)\end{array}$ & 81.26 & 32.40 & 8.20 & 216.00 & 84.68 & 104.21 & 0.797 & -1.255 \\
\hline & \multirow{2}{*}{ SK } & $\begin{array}{l}\text { Control } \\
(n=13)\end{array}$ & 41.21 & 32.40 & 18.20 & 98.80 & 25.19 & 61.13 & 1.368 & 0.503 \\
\hline & & $\begin{array}{c}\text { Restored } \\
(n=13)\end{array}$ & 41.10 & 25.00 & 7.60 & 137.60 & 36.99 & 89.99 & 1.643 & 1.601 \\
\hline
\end{tabular}
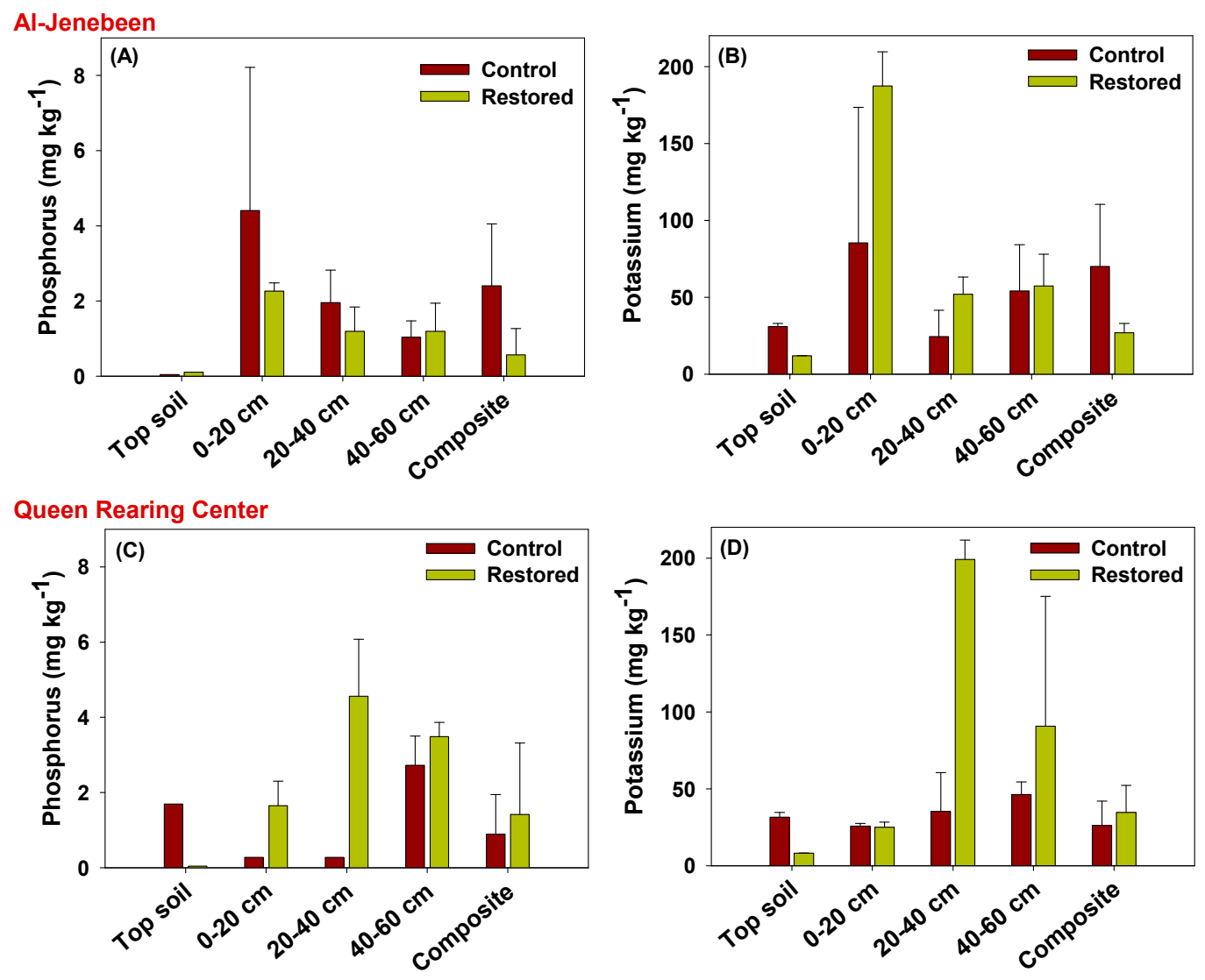

Figure 5. Cont. 

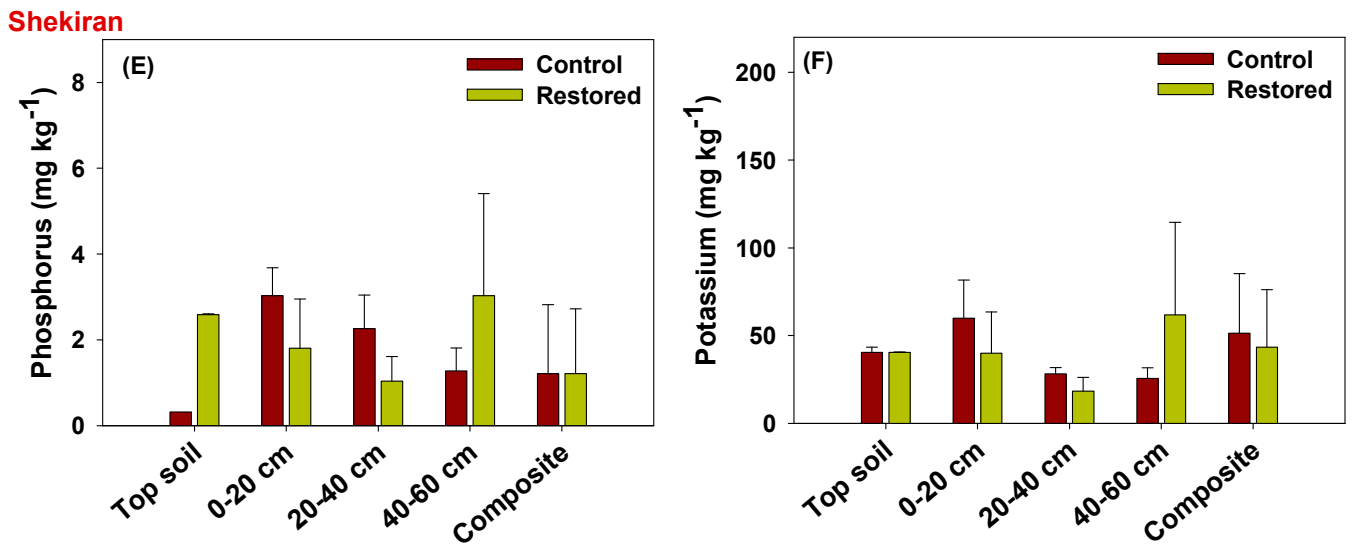

Figure 5. Variations in mean phosphorus and potassium concentrations with soil depth for the samples collected from different localities in southwestern Saudi Arabia ((A): concentration of phosphorus and (B): concentration of potassium in Al-Jenebeen, $(\mathbf{C})$ : concentration of phosphorus and (D): concentration of potassium in Queen Rearing Center, and (E): concentration of phosphorus and (F): concentration of potassium in Shekiran). The error bars represent the standard deviations of the mean values.

Table 5. Descriptive statistics for heavy metals $(\mathrm{Cu}, \mathrm{Fe}, \mathrm{Mn}$, and $\mathrm{Zn})$ concentrations of the soil samples collected from Al-Jenebeen (AJ), Queen Rearing Center (QRC), and Shekiran (SK) in southwestern Saudi Arabia.

\begin{tabular}{|c|c|c|c|c|c|c|c|c|c|c|}
\hline Parameter & Location & Land use & Mean & Median & Min. & Max. & SD & $\mathrm{CV}$ & Skew & Kurtosis \\
\hline \multirow{6}{*}{$\mathrm{Cu}\left(\mathrm{mg} \mathrm{kg}^{-1}\right)$} & \multirow{2}{*}{$\mathrm{AJ}$} & $\begin{array}{l}\text { Control } \\
(n=13)\end{array}$ & 1.61 & 1.21 & 0.67 & 4.12 & 1.05 & 65.25 & 1.466 & 0.854 \\
\hline & & $\begin{array}{l}\text { Restored } \\
(n=13)\end{array}$ & 1.84 & 1.55 & 0.51 & 4.21 & 1.16 & 62.99 & 0.805 & -0.420 \\
\hline & \multirow{2}{*}{ QRC } & $\begin{array}{l}\text { Control } \\
(n=13)\end{array}$ & 1.20 & 1.16 & 0.31 & 2.64 & 0.66 & 54.50 & 0.583 & 0.058 \\
\hline & & $\begin{array}{l}\text { Restored } \\
(n=13)\end{array}$ & 0.97 & 0.82 & 0.31 & 2.02 & 0.58 & 60.15 & 0.732 & -0.665 \\
\hline & \multirow{2}{*}{ SK } & $\begin{array}{l}\text { Control } \\
(n=13)\end{array}$ & 1.32 & 1.48 & 0.36 & 2.46 & 0.71 & 53.99 & 0.088 & -1.270 \\
\hline & & $\begin{array}{c}\text { Restored } \\
(n=13)\end{array}$ & 1.49 & 1.64 & 0.38 & 2.29 & 0.53 & 35.73 & -0.657 & -0.330 \\
\hline \multirow{6}{*}{$\mathrm{Fe}\left(\mathrm{mg} \mathrm{kg}^{-1}\right)$} & \multirow{2}{*}{$\mathrm{AJ}$} & $\begin{array}{c}\text { Control( } \mathrm{n}= \\
13)\end{array}$ & 5.04 & 4.53 & 0.52 & 12.45 & 4.01 & 79.61 & 0.797 & -0.646 \\
\hline & & $\begin{array}{c}\text { Restored } \\
(n=13)\end{array}$ & 4.04 & 2.85 & 0.02 & 8.63 & 2.59 & 64.15 & 0.185 & -1.185 \\
\hline & \multirow{2}{*}{ QRC } & $\begin{array}{l}\text { Control } \\
(n=13)\end{array}$ & 5.79 & 6.82 & 0.00 & 9.28 & 2.61 & 45.12 & -0.804 & -0.211 \\
\hline & & $\begin{array}{l}\text { Restored } \\
(n=13)\end{array}$ & 2.64 & 2.86 & 0.00 & 5.43 & 2.01 & 76.06 & 0.008 & 1.497 \\
\hline & \multirow{2}{*}{ SK } & $\begin{array}{l}\text { Control } \\
(n=13)\end{array}$ & 7.11 & 7.88 & 2.67 & 13.18 & 2.99 & 42.06 & 0.312 & -0.600 \\
\hline & & $\begin{array}{c}\text { Restored } \\
(n=13)\end{array}$ & 7.44 & 7.15 & 3.74 & 11.53 & 2.56 & 34.46 & 0.265 & -1.085 \\
\hline
\end{tabular}


Table 5. Cont

\begin{tabular}{|c|c|c|c|c|c|c|c|c|c|c|}
\hline Parameter & Location & Land use & Mean & Median & Min. & Max. & SD & $\mathrm{CV}$ & Skew & Kurtosis \\
\hline \multirow{6}{*}{$\operatorname{Mn}\left(\mathrm{mg} \mathrm{kg}^{-1}\right)$} & \multirow{2}{*}{$\mathrm{AJ}$} & $\begin{array}{l}\text { Control } \\
(n=13)\end{array}$ & 2.82 & 1.38 & 0.56 & 10.21 & 3.27 & 115.71 & 1.603 & 1.000 \\
\hline & & $\begin{array}{l}\text { Restored } \\
(n=13)\end{array}$ & 1.80 & 1.57 & 0.15 & 4.43 & 1.27 & 70.47 & 0.631 & -0.502 \\
\hline & \multirow{2}{*}{ QRC } & $\begin{array}{l}\text { Control } \\
(n=13)\end{array}$ & 2.82 & 2.61 & 0.09 & 7.67 & 2.40 & 85.13 & 0.618 & -0.776 \\
\hline & & $\begin{array}{l}\text { Restored } \\
(n=13)\end{array}$ & 1.07 & 0.89 & 0.10 & 3.47 & 0.92 & 86.01 & 1.425 & 1.630 \\
\hline & \multirow{2}{*}{ SK } & $\begin{array}{l}\text { Control } \\
(n=13)\end{array}$ & 2.13 & 1.44 & 0.69 & 5.54 & 1.65 & 77.48 & 0.993 & -0.406 \\
\hline & & $\begin{array}{c}\text { Restored } \\
(n=13)\end{array}$ & 3.31 & 1.44 & 0.48 & 15.64 & 4.28 & 129.11 & 2.084 & 3.403 \\
\hline \multirow{6}{*}{$\mathrm{Zn}\left(\mathrm{mg} \mathrm{kg}^{-1}\right)$} & \multirow{2}{*}{$\mathrm{AJ}$} & $\begin{array}{c}\text { Control( }(\mathrm{n}= \\
13)\end{array}$ & 0.25 & 0.03 & 0.00 & 1.39 & 0.45 & 176.19 & 1.829 & 1.802 \\
\hline & & $\begin{array}{c}\text { Restored } \\
(n=13)\end{array}$ & 0.14 & 0.00 & 0.00 & 0.64 & 0.20 & 147.05 & 1.416 & 0.947 \\
\hline & \multirow{2}{*}{ QRC } & $\begin{array}{l}\text { Control } \\
(n=13)\end{array}$ & 0.08 & 0.04 & 0.00 & 0.36 & 0.10 & 135.60 & 1.581 & 1.983 \\
\hline & & $\begin{array}{l}\text { Restored } \\
(n=13)\end{array}$ & 0.12 & 0.00 & 0.00 & 1.09 & 0.32 & 262.62 & 2.431 & 4.495 \\
\hline & \multirow{2}{*}{ SK } & $\begin{array}{l}\text { Control } \\
(n=13)\end{array}$ & 0.13 & 0.03 & 0.00 & 0.58 & 0.18 & 135.61 & 1.279 & 0.787 \\
\hline & & $\begin{array}{l}\text { Restored } \\
(n=13)\end{array}$ & 0.23 & 0.00 & 0.00 & 1.48 & 0.48 & 206.45 & 1.920 & 2.018 \\
\hline
\end{tabular}

The concentration of $\mathrm{Cu}$ increased from 1.61 to $1.84 \mathrm{mg} \mathrm{kg}^{-1}$ and 1.32 to $1.49 \mathrm{mg} \mathrm{kg}^{-1}$ after restoration in the AJ and SK sites, respectively, while it reduced from 1.20 to $0.97 \mathrm{mg} \mathrm{kg}^{-1}$ after restoration in the QRC sites. In the case of $\mathrm{Fe}$, a reduction from 5.04 to $4.04 \mathrm{mg} \mathrm{kg}^{-1}$ and 5.79 to $2.64 \mathrm{mg} \mathrm{kg}^{-1}$ was observed after restoration activities in the AJ and QRC sites, respectively, whereas an increment from 7.11 to $7.44 \mathrm{mg} \mathrm{kg}^{-1}$ was seen in the SK sites with restoration. Similarly, the concentration of Mn reduced from 2.82 to $1.80 \mathrm{mg} \mathrm{kg}^{-1}$ and 2.82 to $1.07 \mathrm{mg} \mathrm{kg}^{-1}$ in the restored areas of $\mathrm{AJ}$ and QRC, respectively, while, on the contrary, it increased from 2.13 to $3.31 \mathrm{mg} \mathrm{kg}^{-1}$ in the restored areas of SK. This trend was even different in the case of $\mathrm{Zn}$, which reduced from 0.25 to $0.14 \mathrm{mg} \mathrm{kg}^{-1}$ after restoration in the $\mathrm{AJ}$ sites, while increasing from 0.08 to $0.12 \mathrm{mg} \mathrm{kg}^{-1}$ and 0.13 to $0.23 \mathrm{mg} \mathrm{kg}^{-1}$ in the QRC and SK sites, respectively, after the restoration. Therefore, these results reflect that there was no specific trend for the variations in the concentrations of micronutrients after land restoration. It is established that the availability of micronutrients is influenced by soil physiochemical and biological properties, such as speciation of the element, concentration of oxides and carbonates, $\mathrm{SOM}$, and $\mathrm{pH}$ [50]. The availability of cationic micronutrients decreases, while the availability of anionic micronutrients increases, with a rise in $\mathrm{pH}$. In the current study, the $\mathrm{pH}$ of the $\mathrm{AJ}$ and QRC sites increased with restoration, while it decreased in the SK sites. This decrease in soil $\mathrm{pH}$ might have resulted in the higher solubility and availability of the micronutrients $(\mathrm{Cu}, \mathrm{Fe}, \mathrm{Mn}$, and $\mathrm{Zn})$. On the contrary, the rise in $\mathrm{pH}$ has subsequently reduced the available portion of $\mathrm{Fe}, \mathrm{Mn}$, and $\mathrm{Zn}$ in the QRC and AJ sites. Moreover, the variations in the concentrations of micronutrients in soil after restoration could also be linked to an unstable soil structure, the uptake of nutrients by the plants, and leaching [51,52]. However, plant-soil interactions should be explored to understand the sustainable restoration of soil and higher availability of floral resources for honeybees. 


\subsection{Correlation Studies}

The correlations between different physiochemical properties ( $\mathrm{pH}, \mathrm{EC}, \mathrm{SOC}, \mathrm{SOM}$, and $\left.\mathrm{CaCO}_{3}\right)$ and soil nutrients $(\mathrm{P}, \mathrm{K}, \mathrm{Cu}, \mathrm{Fe}, \mathrm{Mn}$, and $\mathrm{Zn}$ ) were analyzed via Pearson's correlation coefficients (Table 6). The values of correlation coefficient $\left(r^{2}\right)$ closer to 1 represent a stronger correlation, while the + or - sign shows the type of relationship at a 0.05 level of significance. The calculated correlations suggested a negative correlation of soil $\mathrm{pH}$ with EC $(p<0.05)$ and Fe contents. Moreover, soil Fe, Mn, and $\mathrm{Zn}$ contents were positively correlated with EC $(p<0.05)$. Likewise, soil Fe contents were positively correlated with SOC and SOM $(p<0.05)$. Nan et al. [53] reported the significant positive correlation of micronutrients with SOM. Soil Mn contents were also positively correlated with $\mathrm{P}$ and Fe $(p<0.05)$, while $\mathrm{Zn}$ was positively correlated with Fe and Mn $(p<0.05)$. Pearson correlations is a bivariant method used to investigate the relation between two parameters, thus, the results of the calculated correlation matrix showed some relations between soil available nutrients and soil properties [54]. Soil is a complex system made up of solid, liquid and gaseous phases, as well as various organisms. Therefore, the interpretation of different soil properties and of different types of soils is difficult due to the diversity of characteristics [55]. Therefore, due to varying soil locations, soil characteristics, and nutrient status, the correlations between the various parameters of soil collected from different localities were inconsistent.

Table 6. Pearson correlation coefficients $\left(r^{2}\right)$ and probability $(p)$ as estimated for the relation of different parameters ( $\mathrm{pH}$, electrical conductivity (EC), heavy metals $(\mathrm{Cu}, \mathrm{Fe}, \mathrm{Mn}$, and $\mathrm{Zn}$ ), soil organic carbon (SOC), soil organic matter (SOM), $\mathrm{CaCO}_{3}$, phosphorus (P), and potassium $(\mathrm{K})$ ) of soil samples collected from Al-Jenebeen (AJ), Queen Rearing Center (QRC), and Shekiran (SK) in southwestern Saudi Arabia.

\begin{tabular}{|c|c|c|c|c|c|c|c|c|c|c|c|c|}
\hline$p$ & & Depth & $\mathrm{pH}$ & EC & SOC & SOM & $\mathrm{CaCO}_{3}$ & $\mathbf{P}$ & $\mathbf{K}$ & $\mathrm{Cu}$ & $\mathbf{F e}$ & Mn \\
\hline $\mathrm{pH}$ & $\begin{array}{c}r^{2} \\
p \text {-value }\end{array}$ & $\begin{array}{c}-0.128 \\
0.265\end{array}$ & & & & & & & & & & \\
\hline $\mathrm{EC}$ & $\begin{array}{c}r^{2} \\
p \text {-value }\end{array}$ & $\begin{array}{c}-0.119 \\
0.301\end{array}$ & $\begin{array}{l}-0.295 \\
0.009 *\end{array}$ & & & & & & & & & \\
\hline SOC & $\begin{array}{c}r^{2} \\
p \text {-value }\end{array}$ & $\begin{array}{c}-0.068 \\
0.553\end{array}$ & $\begin{array}{c}-0.148 \\
0.197\end{array}$ & $\begin{array}{c}-0.005 \\
0.967\end{array}$ & & & & & & & & \\
\hline $\mathrm{SOM}$ & $\begin{array}{c}r^{2} \\
p \text {-value }\end{array}$ & $\begin{array}{c}-0.069 \\
0.547\end{array}$ & $\begin{array}{c}-0.147 \\
0.199\end{array}$ & $\begin{array}{c}-0.003 \\
0.979\end{array}$ & $\begin{array}{c}1.000 \\
0.000 \text { * }\end{array}$ & & & & & & & \\
\hline $\mathrm{CaCO}_{3}$ & $\begin{array}{c}r^{2} \\
p \text {-value }\end{array}$ & $\begin{array}{l}0.108 \\
0.348\end{array}$ & $\begin{array}{l}0.139 \\
0.226\end{array}$ & $\begin{array}{c}-0.006 \\
0.958\end{array}$ & $\begin{array}{l}0.113 \\
0.325\end{array}$ & $\begin{array}{l}0.113 \\
0.324\end{array}$ & & & & & & \\
\hline $\mathrm{P}$ & $\begin{array}{c}r^{2} \\
p \text {-value }\end{array}$ & $\begin{array}{l}0.186 \\
0.102\end{array}$ & $\begin{array}{l}0.047 \\
0.685\end{array}$ & $\begin{array}{c}-0.014 \\
0.902\end{array}$ & $\begin{array}{l}0.102 \\
0.372\end{array}$ & $\begin{array}{l}0.101 \\
0.379\end{array}$ & $\begin{array}{c}-0.017 \\
0.881\end{array}$ & & & & & \\
\hline $\mathrm{K}$ & $\begin{array}{c}r^{2} \\
p \text {-value }\end{array}$ & $\begin{array}{l}0.070 \\
0.545\end{array}$ & $\begin{array}{l}0.209 \\
0.067\end{array}$ & $\begin{array}{c}-0.130 \\
0.257\end{array}$ & $\begin{array}{c}-0.032 \\
0.783\end{array}$ & $\begin{array}{c}-0.033 \\
0.773\end{array}$ & $\begin{array}{c}-0.106 \\
0.356\end{array}$ & $\begin{array}{c}0.637 \\
0.000 \text { * }\end{array}$ & & & & \\
\hline $\mathrm{Cu}$ & $\begin{array}{c}r^{2} \\
p \text {-value }\end{array}$ & $\begin{array}{c}-0.023 \\
0.841\end{array}$ & $\begin{array}{l}0.037 \\
0.746 \\
\end{array}$ & $\begin{array}{c}-0.041 \\
0.723\end{array}$ & $\begin{array}{c}-0.001 \\
0.991\end{array}$ & $\begin{array}{c}-0.001 \\
0.992\end{array}$ & $\begin{array}{l}0.019 \\
0.869 \\
\end{array}$ & $\begin{array}{l}0.145 \\
0.204\end{array}$ & $\begin{array}{l}0.105 \\
0.360\end{array}$ & & & \\
\hline $\mathrm{Fe}$ & $\begin{array}{c}r^{2} \\
p \text {-value }\end{array}$ & $\begin{array}{l}0.073 \\
0.525\end{array}$ & $\begin{array}{l}-0.446 \\
0.000 \text { * }\end{array}$ & $\begin{array}{c}0.392 \\
0.000 *\end{array}$ & $\begin{array}{c}0.279 \\
0.013 \text { * }\end{array}$ & $\begin{array}{c}0.280 \\
0.013 \text { * }\end{array}$ & $\begin{array}{c}-0.020 \\
0.865\end{array}$ & $\begin{array}{l}0.003 \\
0.980\end{array}$ & $\begin{array}{c}-0.180 \\
0.115\end{array}$ & $\begin{array}{c}0.297 \\
0.008 \text { * }\end{array}$ & & \\
\hline $\mathrm{Mn}$ & $\begin{array}{c}r^{2} \\
p \text {-value }\end{array}$ & $\begin{array}{l}0.137 \\
0.233\end{array}$ & $\begin{array}{c}-0.191 \\
0.095\end{array}$ & $\begin{array}{c}0.293 \\
0.009 *\end{array}$ & $\begin{array}{l}0.107 \\
0.351 \\
\end{array}$ & $\begin{array}{l}0.107 \\
0.353\end{array}$ & $\begin{array}{c}-0.116 \\
0.311\end{array}$ & $\begin{array}{c}0.353 \\
0.002 \text { * }\end{array}$ & $\begin{array}{l}0.166 \\
0.147\end{array}$ & $\begin{array}{l}0.081 \\
0.483\end{array}$ & $\begin{array}{c}0.496 \\
0.000 \text { * }\end{array}$ & \\
\hline $\mathrm{Zn}$ & $\begin{array}{c}r^{2} \\
p \text {-value }\end{array}$ & $\begin{array}{c}-0.069 \\
0.551\end{array}$ & $\begin{array}{c}-0.034 \\
0.771\end{array}$ & $\begin{array}{c}0.414 \\
0.000 *\end{array}$ & $\begin{array}{l}0.001 \\
0.992\end{array}$ & $\begin{array}{l}0.001 \\
0.991\end{array}$ & $\begin{array}{c}-0.155 \\
0.176\end{array}$ & $\begin{array}{l}0.184 \\
0.107\end{array}$ & $\begin{array}{l}0.061 \\
0.594\end{array}$ & $\begin{array}{l}0.029 \\
0.800\end{array}$ & $\begin{array}{c}0.392 \\
0.000 \text { * }\end{array}$ & $\begin{array}{c}0.638 \\
0.000 \text { * }\end{array}$ \\
\hline
\end{tabular}

* Correlation is significant at the 0.05 level (two-tailed). 


\section{Conclusions}

Soil degradation extent in forests of southwestern Saudi Arabia was evaluated in this study. About 78 samples from Al-Jenebeen (AJ), Queen Rearing Center (QRC), and Shekiran (SK) areas were collected, both from control (no treatment) and restored (restoration activities) areas. Soil physiochemical properties, such as phosphorus (P), potassium (K), $\mathrm{pH}$, electrical conductivity (EC), soil organic matter (SOM), soil organic carbon (SOC), calcite $\left(\mathrm{CaCO}_{3}\right)$, texture, and micronutrients $(\mathrm{Cu}, \mathrm{Zn}, \mathrm{Fe}$, and $\mathrm{Mn})$, were determined. The data of soil physical and chemical properties showed inconsistent trends and larger variations. Overall, all the soil had lower SOM and nutrient contents, however, the soils were slightly alkaline and nonsaline. The results exhibited that sandy loam was the most dominant textural class in all the studied sites $(\sim 60 \%)$, followed by sandy clay loam. The variations in soil properties with restoration activities were inconstant. SK soil exhibited relatively prominent positive effects of restoration practices, as compared to QRC and AJ soils, as predicted by the highest $\mathrm{SOC}$ retention, reduced $\mathrm{pH}$, and retention of nutrients. Therefore, currently, restored areas in SK could be beneficial for honeybee production due to the higher availability of floral resources. However, identifying the existing plant resources, soil physiochemical characteristics, and restoration potential of the study areas must be explored more for sustainable honeybee flourishing. Therefore, it was concluded that further temporal studies are needed to explore the long term effects of restoration activities on rehabilitation potential in the Al-baha region of Saudi Arabia.

Author Contributions: Conceptualization, project administration, resources and methodology, A.A.A.-G.; investigation and review and editing, Y.T.; software and visualization, N.A.; validation, formal analysis, writing and review and editing, A.G.A. All authors have read and agreed to the published version of the manuscript.

Funding: This project was funded by the National Plan for Science, Technology and Innovation (MAARIFAH), King Abdulaziz City for Science and Technology, Kingdom of Saudi Arabia, Award Number (13-AGR2118-02).

Institutional Review Board Statement: Not applicable.

Informed Consent Statement: Not applicable.

Data Availability Statement: Not applicable.

Acknowledgments: The authors extend their appreciation to the National Plan for Science, Technology and Innovation (MAARIFAH), King Abdulaziz City for Science and Technology, Kingdom of Saudi Arabia, Award Number (13-AGR2118-02).

Conflicts of Interest: The authors declare no conflict of interest.

\section{References}

1. Mesfin, S.; Taye, G.; Desta, Y.; Sibhatu, B.; Muruts, H.; Mohammedbrhan, M. Short-Term Effects of Bench Terraces on Selected Soil Physical and Chemical Properties: Landscape Improvement for Hillside Farming in Semi-Arid Areas of Northern Ethiopia. Environ. Earth. Sci. 2018, 77, 399. [CrossRef]

2. Alves, L.F.; Vieira, S.A.; Scaranello, M.A.; Camargo, P.B.; Santos, F.A.M.; Joly, C.A.; Martinelli, L.A. Forest Structure and Live Aboveground Biomass Variation along an Elevational Gradient of Tropical Atlantic Moist Forest (Brazil). For. Ecol. Manag. 2010, 260, 679-691. [CrossRef]

3. Lamb, D.; Erskine, P.D.; Parrotta, J.A. Restoration of Degraded Tropical Forest Landscapes. Science 2005, 310, 1628-1632. [CrossRef] [PubMed]

4. León, J.D.; Osorio, N.W. Role of Litter Turnover in Soil Quality in Tropical Degraded Lands of Colombia. Sci. World J. 2014, 2014, e693981. [CrossRef]

5. Lal, R. Restoring Soil Quality to Mitigate Soil Degradation. Sustainability 2015, 7, 5875-5895. [CrossRef]

6. Martínez, F.J.; Sierra, M.; Sierra, C.; Roca, A. Assessing Sustainable Use of Land under Olive Cultivation in Alcala La Real (Jaen, Spain) Using GIS. Adv. Geoecol. 2005, 36, 75-84.

7. Khresat, S.A.; Qudah, E.A. Formation and Properties of Aridic Soils of Azraq Basin in Northeastern Jordan. J. Arid Environ. 2006, 64, 116-136. [CrossRef]

8. Mbagwu, J.S.C. Aggregate Stability and Soil Degradation in the Tropics; ETDEWEB: Trieste, Italy, 2004; pp. 246-252. Available online: http:/ / users.ictp.it/ \{\}pub_off/lectures/lns018/22Mbagwu1.pdf (accessed on 10 December 2020). 
9. Kremen, C.; Williams, N.M.; Thorp, R.W. Crop Pollination from Native Bees at Risk from Agricultural Intensification. Proc. Natl. Acad. Sci. USA 2002, 99, 16812-16816. [CrossRef]

10. Isaacs, R.; Williams, N.; Ellis, J.; Pitts-Singer, T.L.; Bommarco, R.; Vaughan, M. Integrated Crop Pollination: Combining Strategies to Ensure Stable and Sustainable Yields of Pollination-Dependent Crops. Basic Appl. Ecol. 2017, 22, 44-60. [CrossRef]

11. Koh, I.; Lonsdorf, E.V.; Williams, N.M.; Brittain, C.; Isaacs, R.; Gibbs, J.; Ricketts, T.H. Modeling the Status, Trends, and Impacts of Wild Bee Abundance in the United States. Proc. Natl. Acad. Sci. USA 2016, 113, 140-145. [CrossRef]

12. Biesmeijer, J.C.; Roberts, S.P.M.; Reemer, M.; Ohlemüller, R.; Edwards, M.; Peeters, T.; Schaffers, A.P.; Potts, S.G.; Kleukers, R.; Thomas, C.D.; et al. Parallel Declines in Pollinators and Insect-Pollinated Plants in Britain and the Netherlands. Science 2006, 313, 351-354. [CrossRef]

13. Kovács-Hostyánszki, A.; Espíndola, A.; Vanbergen, A.J.; Settele, J.; Kremen, C.; Dicks, L.V. Ecological Intensification to Mitigate Impacts of Conventional Intensive Land Use on Pollinators and Pollination. Ecol. Lett. 2017, 20, 673-689. [CrossRef] [PubMed]

14. Al-Ghamdi, A.A.; Tadesse, Y.; Adgaba, N. Evaluation of Major Acacia Species in the Nursery towards Apicultural Landscape Restoration around Southwestern Saudi Arabia. Saudi J. Biol. Sci. 2020, 27, 3385-3389. [CrossRef]

15. Ryan, J.; Estefan, G.; Rashid, A. Soil and Plant Analysis Laboratory Manual; ICARDA-Jointly published by International Center for Agricultural Research in Dry areas, Syria and The National Agriculture Research Center: Islamabad, Pakistan, 2001; ISBN 978-92-9127-118-4.

16. Koehler, F.E.; Moodie, C.D.; McNeal, B.L. Laboratory Manual for Soil Fertility; Washington State University: Pulman, WA, USA, 1984.

17. Horváth, B.; Opara-Nadi, O.; Beese, F. A Simple Method for Measuring the Carbonate Content of Soils. Soil Sci. Soc. Am. J. 2005, 69, 1066-1068. [CrossRef]

18. Walkley, A.; Black, I.A. An examination of the degtjareff method for determining soil organic matter, and a proposed modification of the chromic acid titration method. Soil Sci. 1934, 37, 29-38. [CrossRef]

19. Soltanpour, P.N.; Schwab, A.P. A New Soil Test for Simultaneous Extraction of Macro- and Micro-nutrients in Alkaline Soils. Commun. Soil Sci. Plant Anal. 1977, 8, 195-207. [CrossRef]

20. Pattison, A.B.; Moody, P.W.; Badcock, K.A.; Smith, L.J.; Armour, J.A.; Rasiah, V.; Cobon, J.A.; Gulino, L.-M.; Mayer, R. Development of Key Soil Health Indicators for the Australian Banana Industry. Appl. Soil Ecol. 2008, 40, 155-164. [CrossRef]

21. Khadka, D.; Lamichhane, S.; Shrestha, K.; Joshi, S.; Karna, M.; Pant, B.B.; Yadav, S. Soil Fertility Assessment and Mapping of Agricultural Research Station, Jaubari, Illam, Nepal. Int. J. Environ. 2017, 6, 46-70. [CrossRef]

22. Tadesse, B.; Mesfin, S.; Tesfay, G.; Abay, F. Effect of Integrated Soil Bunds on Key Soil Properties and Soil Carbon Stock in Semi-Arid Areas of Northern Ethiopia. S. Afr. J. Plant Soil 2016, 33, 297-302. [CrossRef]

23. Wang, X.P.; Li, X.R.; Xiao, H.L.; Pan, Y.X. Evolutionary Characteristics of the Artificially Revegetated Shrub Ecosystem in the Tengger Desert, Northern China. Ecol. Res. 2006, 21, 415-424. [CrossRef]

24. Hartemink, A.E. Soil Chemical and Physical Properties as Indicators of Sustainable Land Management under Sugar Cane in Papua New Guinea. Geoderma 1998, 85, 283-306. [CrossRef]

25. Shukla, A.; Vyas, D.; Anuradha, J. Soil Depth: An Overriding Factor for Distribution of Arbuscular Mycorrhizal Fungi. J. Soil Sci. Plant Nutr. 2013, 13, 23-33. [CrossRef]

26. Zhang, Y.L.; Chen, L.J.; Chen, X.H.; Tan, M.L.; Duan, Z.H.; Wu, Z.J.; Li, X.J.; Fan, X.H. Response of Soil Enzyme Activity to Long-Term Restoration of Desertified Land. Catena 2015, 133, 64-70. [CrossRef]

27. Scianna, J. Salt-Affected Soils: Their Causes, Measure, and Classification. Res. Method Hort. Note 2002, 5, 1-3.

28. He, B.; Cai, Y.; Ran, W.; Jiang, H. Spatial and Seasonal Variations of Soil Salinity Following Vegetation Restoration in Coastal Saline Land in Eastern China. Catena 2014, 118, 147-153. [CrossRef]

29. Bezborodov, G.A.; Shadmanov, D.K.; Mirhashimov, R.T.; Yuldashev, T.; Qureshi, A.S.; Noble, A.D.; Qadir, M. Mulching and Water Quality Effects on Soil Salinity and Sodicity Dynamics and Cotton Productivity in Central Asia. Agric. Ecosyst. Environ. 2010, 138, 95-102. [CrossRef]

30. Krull, E.S.; Skjemstad, J.O.; Baldock, J.A. Functions of Soil Organic Matter and the Effect on Soil Properties; Cooperative Research Centre for Greenhouse Accounting: Canberra, Australia, 2004.

31. Obalum, S.E.; Okpara, I.M.; Obi, M.E.; Wakatsuki, T. Short Term Effects of Tillage-Mulch Practices under Sorghum and Soybean on Organic Carbon and Eutrophic Status of a Degraded Ultisol in Southeastern Nigeria. Trop. Subtrop. Agroecosyst. 2011, 14, 393-403.

32. Spaccini, R.; Piccolo, A.; Mbagwu, J.S.C.; Teshale, A.Z.; Igwe, C.A. Influence of the Addition of Organic Residues on Carbohydrate Content and Structural Stability of Some Highland Soils in Ethiopia. Soil Use Manag. 2002, 18, 404-411. [CrossRef]

33. du Preez, C.C.; van Huyssteen, C.W.; Mnkeni, P.N.S. Land Use and Soil Organic Matter in South Africa 2: A Review on the Influence of Arable Crop Production. S. Afr. J. Sci. 2011, 107, 35-42. [CrossRef]

34. Kalinina, O.; Cherkinsky, A.; Chertov, O.; Goryachkin, S.; Kurganova, I.; Lopes de Gerenyu, V.; Lyuri, D.; Kuzyakov, Y.; Giani, L. Post-Agricultural Restoration: Implications for Dynamics of Soil Organic Matter Pools. Catena 2019, 181, 104096. [CrossRef]

35. Hoyle, F.C.; Baldock, J.A.; Murphy, D.V. Soil Organic Carbon-Role in Rainfed Farming Systems. In Rainfed Farming Systems; Tow, P., Cooper, I., Partridge, I., Birch, C., Eds.; Springer: Dordrecht, The Netherlands, 2011; pp. 339-361. ISBN 978-1-4020-9132-2.

36. Dexter, A.R.; Pagliai, M.; Jones, R. Soil Structure: The Key to Soil Function. Adv. GeoEcol. 2002, 35, 57-69. 
37. Banaszak-Cibicka, W.; Takacs, V.; Kesy, M.; Langowska, A.; Blecharczyk, A.; Sawinska, Z.; Sparks, T.H.; Tryjanowski, P. Manure application improves both bumblebee flower visitation and crop yield in intensive farmland. Basic Appl. Ecol. 2019, 36, 26-33. [CrossRef]

38. Sáez, A.; Morales, C.L.; Ramos, L.Y.; Aizen, M.A. Extremely frequent bee visits increase pollen deposition but reduce drupelet set in raspberry. J. Appl. Ecol. 2014, 51, 1603-1612. [CrossRef]

39. Baldock, J.; Skjemstad, J.O. Soil Organic Carbon/Soil Organic Matter; CSIRO Publishing: Collingwood, VIC, Australia, 1999; ISBN 978-0-643-06376-1.

40. Tashi, S.; Singh, B.; Keitel, C.; Adams, M. Soil carbon and nitrogen stocks in forests along an altitudinal gradient in the eastern Himalayas and a meta-analysis of global data. Glob. Chang. Biol. 2016, 22, 2255-2268. [CrossRef] [PubMed]

41. do Carmo, F.F.; Jacobi, C.M. Diversity and plant trait-soil relationships among rock outcrops in the Brazilian Atlantic rainforest. Plant Soil 2016, 403, 7-20. [CrossRef]

42. Rowley, M.C.; Grand, S.; Verrecchia, É.P. Calcium-Mediated Stabilisation of Soil Organic Carbon. Biogeochemistry 2018, 137, 27-49. [CrossRef]

43. Dong, S.K.; Wen, L.; Li, Y.Y.; Wang, X.X.; Zhu, L.; Li, X.Y. Soil-Quality Effects of Grassland Degradation and Restoration on the Qinghai-Tibetan Plateau. Soil Sci. Soc. Am. J. 2012, 76, 2256-2264. [CrossRef]

44. Chen, D.D.; Zhang, S.H.; Dong, S.K.; Wang, X.T.; Du, G.Z. Effect of Land-Use on Soil Nutrients and Microbial Biomass of an Alpine Region on the Northeastern Tibetan Plateau, China. Land Degrad. Dev. 2010, 21, 446-452. [CrossRef]

45. Feng, R.; Long, R.; Shang, Z.; Ma, Y.; Dong, S.; Wang, Y. Establishment of Elymus Natans Improves Soil Quality of a Heavily Degraded Alpine Meadow in Qinghai-Tibetan Plateau, China. Plant Soil 2010, 327, 403-411. [CrossRef]

46. Wu, G.L.; Liu, Z.H.; Zhang, L.; Hu, T.M.; Chen, J.M. Effects of Artificial Grassland Establishment on Soil Nutrients and Carbon Properties in a Black-Soil-Type Degraded Grassland. Plant Soil 2010, 333, 469-479. [CrossRef]

47. Xu, H.; Qu, Q.; Li, P.; Guo, Z.; Wulan, E.; Xue, S. Stocks and Stoichiometry of Soil Organic Carbon, Total Nitrogen, and Total Phosphorus after Vegetation Restoration in the Loess Hilly Region, China. Forests 2019, 10, 27. [CrossRef]

48. Barreto, P.A.B.; Gama-Rodrigues, E.F.; Gama-Rodrigues, A.C.; Fontes, A.G.; Polidoro, J.C.; Moço, M.K.S.; Machado, R.C.R.; Baligar, V.C. Distribution of Oxidizable Organic C Fractions in Soils under Cacao Agroforestry Systems in Southern Bahia, Brazil. Agrofor. Syst. 2011, 81, 213-220. [CrossRef]

49. Ruiz-Sinoga, J.D.; Diaz, A.R. Soil Degradation Factors along a Mediterranean Pluviometric Gradient in Southern Spain. Geomorphology 2010, 118, 359-368. [CrossRef]

50. Seenivasan, R.; Prasath, V.; Mohanraj, R. Restoration of Sodic Soils Involving Chemical and Biological Amendments and Phytoremediation by Eucalyptus Camaldulensis in a Semiarid Region. Environ. Geochem. Health 2015, 37, 575-586. [CrossRef]

51. Nicholson, F.A.; Smith, S.R.; Alloway, B.J.; Carlton-Smith, C.; Chambers, B.J. Quantifying Heavy Metal Inputs to Agricultural Soils in England and Wales. Water Environ. J. 2006, 20, 87-95. [CrossRef]

52. Qadir, M.; Tubeileh, A.; Akhtar, J.; Larbi, A.; Minhas, P.S.; Khan, M.A. Productivity Enhancement of Salt-Affected Environments through Crop Diversification. Land Degrad. Dev. 2008, 19, 429-453. [CrossRef]

53. Nan, Z.; Zhao, C.; Li, J.; Chen, F.; Sun, W. Relations Between Soil Properties and Selected Heavy Metal Concentrations in Spring Wheat (Triticum Aestivum L.) Grown in Contaminated Soils. Water Air Soil Pollut. 2002, 133, 205-213. [CrossRef]

54. Sharma, M.R.; Raju, N.S. Correlation of Heavy Metal Contamination with Soil Properties of Industrial Areas of Mysore, Karnataka, India by Cluster Analysis. Int. J. Environ. Sci. 2013, 2, 22-27.

55. Ludovisi, A.; Minozzo, M.; Pandolfi, P.; Taticchi, M.I. Modelling the Horizontal Spatial Structure of Planktonic Community in Lake Trasimeno (Umbria, Italy) Using Multivariate Geostatistical Methods. Ecol. Modell. 2005, 181, 247-262. [CrossRef] 